Juhan Maiste

\title{
THE CONCEPT OF RUSSIAN ARCHITECTURE IN THE BALTIC PROVINCES BETWEEN THE GREAT NORTHERN WAR AND THE COSMOPOLITANISM OF THE 19TH CENTURY
}

The source of inspiration for this article comes from materials by Segey Androsov and Georgy Smirnov that appear in this issue, and his son-in law Giuseppe Trezzini by Georgy Smirnov that appear in this issue, and which provide a new opportunity to re-examine the problems of Russian impact in Estonia that Heinz Pirang ${ }^{1}$, Voldemar Vaga $^{2}$, Helmi Üprus ${ }^{3}$, Mai Lumiste ${ }^{4}$ have dealt with, and which has most recently been given a new direction the third volume of the History of Estonian Art. ${ }^{5}$

DOI: https:/ / doi.org/10.12697/BJAH.2019.17.05

Translated by Juta Ristsoo.

1 Heinz Pirang, Das Baltische Herrenhaus, Teil II, Die Blütezeit um 1800 (Riga: Jonck \& Poliewsky, 1928).

2 Voldemar Vaga, Vene arhitektide ja skulptorite teoseid baroki-ja klassitsismi-ajajärgust Eestis (Tartu: Teaduslik Kirjandus, 1947).

3 Helmi Üprus, 'XIX sajandi esimese poole ehitusmälestised', Eesti arhitektuuri ajalugu (Tallinn: Eesti Raamat, 1965), 333ff.

4 Mai Lumiste, 'Kunst Eestis 17. sajandi 30-ndatest aastatest kuni 18. sajandi 80-ndate aastateni', Eesti kunsti ajalugu, 1 (Tallinn: Kunst, 1975), 105ff.

5 Eesti kunsti ajalugu, 3 (1770-1840), ed. by Juhan Maiste (Tallinn: Eesti Kunstiakadeemia, 2017). 
In the broadest sense, the goal of this article is to examine the mission of the new power related to cultural policy in the Baltic provinces since the Great Northern War (1700-1721) and up to the Russian Revolution (1917), to engender a discussion about the Russian influence in the architectural history of Estonia - its content and meaning, based on new primarily sources from the archives of Estonia, St Petersburg and Moscow. By defining an entire process of art history that started with Peter the Great and achieved its culmination in the form of the early 19th century Neoclassicism as 'Russian-influenced architecture', we have only scratched the surface of a much broader phenomenon. We are dealing with an invasion and impulses that brought high-quality international art to the Baltic provinces and provided a 'border country' with a unique position in regard to the adaptation and interpretation of an international art experience. With the help of which the distant glow of northern lights in the dark nocturnal sky of the Nordic countries and a reflection of the light that had ignited in Rome, Paris and Berlin and which, intermediated by St Petersburg, provided new inspiration to the art life in the province and paved the way to a cosmopolitan cultural horizon.

\section{A GERMAN TOWN AND ITALIAN ARCHITECTS}

The Great Northern War brought about a fundamental change in the political situation in the Baltic provinces. From the viewpoint of the great power, the peace treaty signed in 1710 at Harku Manor was the fulfilment of a long-time dream to establish a so-called 'window to Europe'. And the achievement of this dream was announced in the form of a new aesthetical programme - which included the construction by Peter the Great of his summer palace in Kadriorg (Catherinenthal), as well as various seaports and city fortifications; and last but not least, the introduction of the Orthodox religion alongside Lutheranism, and the construction of the necessary houses of worship. However, the question remains, how deeply did the initiatives of the central government affect the spiritual relations that have developed over the centuries, and what was the actual role of the new utopia in a province where the German language and mentality lived on? Architecture had an important role to play as the rhetorical messenger of the changes that had taken place.

Along with the close proximity of St Petersburg, the colonisation process was also characterised by the opposite trend. The local society, which was traditionally linked to the West, and orientated toward the models from Saxony, Mecklenburg, and SchleswigHolstein, dominated in both urban construction and the manors of the nobility for a long time after the land was transferred to the new ruler. On the other hand the aristocracy of the Baltic provinces was welcomed to the Tsarist court. The ancient local noble families found a place in the political life, culture and even more in the army, where the Balts got the special place and were treated as foreigners, something that according to the Ukase of 1729, they received salaries that were twice as large as those paid to Russian officers. ${ }^{6}$ Instead of being the colony of the huge empire, in reality Estonia became the status of the buffer zone in between West and East, where many processes developed faster, giving the 'noblemen republic' the German name Gelehrtenrepublik.

By selecting individual facts from art history, we are inevitably faced by the problem of art geography in a more broader sense. The artistic will that was derived from the faraway metropolis, which initially seemed foreign, did not find support in the provinces until several decades had passed. Only in the course of the cultural integration, the cosmopolitan artistic culture and its visual icons were adopted. What was once strange became familiar; under conditions of political engagement, the disconnected cultural fragments were combined into a complete picture, which was both homogeneous and heterogeneous, one's own and foreign - something that has characterised Baltic culture through the centuries. As Heinrich Johann von Jannau, the man of letters wrote, 'Everything that exists in Rome, Naples, Dresden and Berlin must definitely also exist here' ${ }^{7}$. Whereas it is difficult to say whether

6 A total of 725 officers from the Baltic provinces participated in the war against Napoleon; the most distinguished of them were Barclay de Tolly from Valga County, hi Friedrich von Toll, and others. Tõnu Tannberg 'Baltisakslasena impeeriumi teenistuses', Woldemar von Löwenstern, Ühe liivimaalase mälestused (aastatest 1790-1815) (Tallinn Varrak, 2017) 406. Theodor Bernhardi, Kindral Carl von Toll (1777-1842). Aruküla (Tartu: Greif, 1999), 313.

7 Heinrich Johann von Jannau, Sitten und Zeit, ein Memorial an Lief- und Estlands Väter (Riga: Johann Friedrich Hartknoch, 1781), 65. 
this involves cultural adaptation or invasion. How and in what context should we read Russia's own architectural history: 'If only Italians had been invited here (to St Petersburg - J. M.), Italian Baroque would be apparent in its architecture. But if only Germans had come, they would have brought along influences from North or South Germany. A much more severe appearance would have been provided by the French. Or even more so by the Dutch. So, these masters worked collectively, and often, on one and the same building. $^{\prime 8}$

Almost a hundred years had to pass before one could speak of the blending of various impulses inherited from Europe became to play their own role in Russia.. ${ }^{9}$ The same apparently applies to the Baltic provinces where, starting in the late 18th century, the contributions of Niccolò Michetti, Francesco Bartolomeo Rastrelli and Trezzini were supplemented by Giacomo Quarenghi, Luigi Rusca as well as Carlo Rossi. France was also heard along with Italy. Around the $1800 \mathrm{~s}$, there is a reason to increasingly separate purely Russian architecture - the influence of Neoclassicism and Empire style - from the general picture. The common denominator of the cultural identity of the period under examination was and continued to be Germany, where most of the architects and artists in the Baltic provinces came from, and whose ideas and social circles united the land with the era of Goethe Zeit and Biedermeier. This again raises the question of whether a phenomenon such as Russian architecture even exists in the Baltic countries, or are we just dealing with the adaptation of German, Italian and French architectural impulses to a new historical situation? $?^{10}$

In order to be able to answer the fundamental question about the cosmopolitical character of the Baltic architectural world, one needs to start from the beginning. The tsar's undertakings in Tallinn, now a military and garrison town, were unlike anything else occurring in the surrounding environment, which as a whole was suffering

8 Igor E. Grabar, Istoriya Russkogo Iskusstva. Arhitektura, Tom 3 (Moscow: Izdanie I Knebel, 1910), 27.

9 Elena A. Borisova, 'Arhitektura Peterburga', Istoriya Russkogo Iskusstva, Tom 14 ed. by Grigory Iu. Sternin. Iskusstvo pervoi treti XIX veka (Moscow: Sev Pal, 2011), 24 10 Nils Erik Wickberg, 'Veneläisia Piirteita Baltilaisessa Empirearkkitehtuurissa', (1981), 49 . from the wounds of war and seized by new military utopias. ${ }^{11}$ On the territory of a summer manor (Höfchen) below the Lasnamägi Klint Plateau, the tsar had a modest little house renovated into a liveable residence. As Wilhelm von Delden, the Supreme Commander of Tallinn, wrote in 1718: 'The tsar's palace in a coppice, where his highness deigns to stay when he arrives in Reval is quite dilapidated, somewhat rotten, and thereby posing the danger that an accident could happen if it collapses. I am demanding whatever is necessary from your Excellency to repair the old building. ${ }^{\prime 2}$ The small house of the emperor was succeeded by the tsar's summer palace on the seaside, with which the architect brought a bright caput mundi light to the old Hanseatic town that has suffered from war and plague epidemics but at the same time was ready for the new revival.

The architect of the palace Niccolò Michetti was a star, whose source of inspiration had been the Roman villas and palaces, from Villa Pamphili to Villa Borghese, Palazzo Senatorio by Giacomo della Porta and Girolamo Rainaldi, and Palazzo Montecitorio begun by Bernini and completed by his pupil Carlo Fontana. Before arriving in Russia, the architect had worked as a foreman (Capomaestro) for Carlo Fontana during the reconstruction of the basilica of Santi Apostoli. He also built the church of St John the Apostle in Zagarolo and many smaller architectural edifices, such as the Sacripante Chapel (1712) in Sant'Ignazio. By the time Michetti arrived in Russia, his approach, which we have become accustomed to associating with so-called Roman Baroque, was changing. This along with the passion of Italy, highlighted French esprit and its noble simplicité. In Kadriorg we encounter a type of villa that is focused on the articulation of variety and a sophistic multi-faceted association with the landscape and

11 In 1710, a plan was developed by Russian military engineers that called for the completion of the bastion zone started by the Swedish military engineers. Russian State Military History Archive [Rossiiskii gosudarstvennyi voenno-istoricheskii arkhiv, RGVIA], 349 (Reval 1505). Already in 1711, Peter the Great sent his adjutant, General Anthony Devier, Tallinn to ascertain the best possibilities for defending the town of Tallinn, the fortress and port agains the Swedes. A. Le Blónde's plan for building a naval port in Tallinn dates from 1717. (Jür Kuuskemaa, Peeter I ja Katariina I Tallinnas (Tallinn: Valgus, 2004), 43.) Throughout the 18th century, ever more new plans were drawn up for the construction of naval ports in both Paldiski and Tallinn. One of the more noteworthy plans was prepared by Jacob Eduard de Witte a Dutch lieutenant engineer, after the appearance of Swedes forces at anchorage in Tallinn in 1792. (National Archives of Estonia [Rahvusarhiiv, RA, EAA].854.4.478). The last larger plan to change the town into a giant military platform surrounding Toompea Hill was produced by architect Johann Daniel Bantelmann in 1820. RGVIA, 3 (L.), 464.

12 Kuuskemaa, Peeter I ja Katariina I Tallinnas, 26. 
surrounding nature, rather than the monumentality of the building volume; where the cogito discourse of Descartes was replaced by the concept familiar to Leibnitz 'monads' and the unique genius loci of the place. ${ }^{13}$ Undoubtedly, Michetti was also familiar with the era's most modern French palaces.

Domenico Trezzini had entered the service of Peter the Great before Michetti did. He had arrived in St Petersburg already in 1703, where he substantially contributed to its most representative buildings: the Peter and Paul Fortress with the Peter and Paul Cathedral, the Twelve Collegia Building as well as Peter's Summer House. The style, and even more the roots, of the architecture proposed by Trezzini, was different than Michetti's. Born in Switzerland in the vicinity of Lugano, Trezzini brought together the architectural idiom, the keywords of which are simplicity and clarity, and which 'in the form of Northern Italian Baroque had acquired more of a graphic than volumetric nature.'14 The prerequisites for Trezzini's experience in the field of civil architecture were the classical principles which in the context of economical demands to the architecture familiar to the Protestant world form the general background of his artistic cosmos. In many ways, in Trezzini's approach, the South meets the North. And this created a distinction between the massive plan of the Italian buildings with their central hallways and the enfilade plan of the French buildings, thereby making the latter, which was already familiar from the buildings of Sebastiano Serlio, the preferred style for aristocratic palaces and villas. ${ }^{15}$

Thanks to Serlio's intellectual capacity as well as practicality, these principles were quickly adapted in Northern Europe. ${ }^{16}$ In the buildings of Trezzini in St Petersburg, one can distinguish the

13 Juhan Maiste, 'The Park and the Baroque Universe', Kadriorg 295 - A Baroque Park Nowadays, ed. by Marika Valk (Tallinn: Kadrioru Park, 2014), 28ff.

14 Dmitry Schwidkovsky, 'The Architecture of the Russian State: Between East and West, 1600-1760', The Triumph of the Baroque. Architecture in Europe 1600-1750, ed. by Henry A. Millon (London: Thames \& Hudson, 1999), 152

15 Myra Nan Rosenfeld, Serlio on Domestic Architecture (Mineola, New York: Dover Publications, 1978), 51.

16 Sabine Frommel, Sebastiano Serlio, Architecte de la Renaissance (Milan: Electa, 1998), 9. examples presented in Serlio's Book VI. ${ }^{17}$ In comparison to the early traditions of Renaissance (Alberti, Filarete, Francesco di Giorgia) the models what appear in the sixth volume are fundamentally different. It is symptomatic that Serlio is interested in the building culture of the middle classes and problems of construction of the series of edifices of their dwelling houses..$^{18}$ Along with solutions based on the classics Serlio also knew how to take the specifics of the medieval city into account, whereby the buildings can to be placed on the narrow lots so that they would create an unbroken and well-ordered row along that street that was based on the rules of classical harmony.

Little is known of Trezzini's early life. It has been assumed that Trezzini had ties to Rome, ${ }^{19}$ where the city in ruins was steadily growing into an enormous Theatrum Mundi, with its grandiosi, superbo and magnifico: superior churches, palaces, gardens and, last but not least, with a new city plan based on a Gesamtkunstwerk agenda. ${ }^{20}$ On the other hand, Paris, which starting from the 1670s as it rose to rival Rome, determined the architectural taste of the era. After presenting the plans for the east facade of the Louvre to the author the great Bernini, was sent back home with tributes. In the Royal Academy of Architecture in France the concept of buono gusto was replaced by bon gout. In urban planning, this finally resulted in a change that had started with the emergence of the rationality and social determinism, which had already been apparent in the era of Henry IV. ${ }^{21}$ The burgeoning encyclopaedic spirit was accompanied by a respect for order and systems. Just like nature, the cities were also divided into classes and families, where each individual structure had a definite location and form. ${ }^{22}$

17 Sebastiano Serlio's Book VI on architecture remained popular during the architect's lifetime, and also in France and Cermany during the 16th and 17th century as woodcuts

18 Frommel, Sebastiano Serlio, Architecte de la Renaissanc, 352.

19 Konstantin V. Malinovsky, Dominiko Trezini (Sankt-Peterburg: Kriga, 2007), 6.

20 Wolfgang Jung, 'Architektur und Stadt in Italien zwischen Frühbarock und Frühklassizismus', Die Kunst des Barock. Architektur, Skulptur, Malerei, ed. by Rolf Toman (Köln: Könemann Verlag, 1997), 12

21 Anthony Blunt, Art and Architecture in France, 1500-1700 (New Haven, London: Yale University Press / Pelican History of Art, 1998), 102ff.

22 Christian Norberg-Schulz, 'The Age of Late Baroque and Rococo', The Triumph of the Baroque Architecture in Europe 1600-1750, ed. by Henry A. Millon (London: Thames \& Hudson, 1999), 113. 
It is known, that from 1699 to 1703 , Trezzini was involved in the royal building commission in Denmark, where he was probably associated with the construction of the Copenhagen Stock Exchange building. ${ }^{23}$ Beside Italy, the French and German architectural treatises, which most probably were on his writing desk, his handwriting was influenced by Palladianism, as well on the other hand, on the modern interpretation of the classics by Claude Perrault and François Blondel Sr. As already, Joseph Furttenbach wrote in 1628, 'architecture in Italy is of greater worth, more artistic and revered than anything that can be seen elsewhere in Europe... A large diele (vestibule) is located on the ground floor, with living rooms on the first and second floors, and weapons room, art chamber and library on the top floor. ${ }^{24}$

'Royal and princely palaces are inspired by Roman and Greek models,' writes Leonhard Christoph Sturm, 'their direct models are the publications of Palladio, Scamozzi and Perrault.'25 Yet thereafter, it is only the construction in the unique - i.e. German - style that ensures the German comfort (Commodität der Teutschen Gebäude), provides an opportunity to associate architecture with both the requirements of society and the existing climatic conditions. ${ }^{26}$ Thereby, the Italian 'exaggerations' were abandoned. Instead of Vitruvian columns we find a simplified version of the order: pilasters dividing symmetrically designed facades, entrances that are located on the central axis, and spacious halls with staircases behind them. In architectural history, this minimalist approach to the classical canon has been described as Säulenlos (without columns) ${ }^{27}$, which, as such is well-suited to the Protestant taste context and the architectural

23 Malinovsky, Dominiko Trezini, $8 \mathrm{ff}$.

24 Joseph Furttenbach, Architectura Civilis. Das ist: Eigentlich Beschreibung, wie man nach bester Form und gerechter RegullFürs Erste... (Ulm: Saur, 1628).

25 Leonhard Christoph Sturm, Vollständige Anweisung, Grosser Herren Palläste starck, bequem, nach den Regeln der antiquen Architektur untadelich, und nach dem heutigen Gusto schön und prächtig anzugeben (Augspurg: Jeremiae Wolffens, 1752), 3.

26 Leonhard Christoph Sturm, Erste Ausübung der Vortreflichen und Vollständigen Anzweisung Zu der Cizil-Bau-Kunst, Nikolai Coldmanns in Neuen Ausführlichen Anuterkungen (Braunschweig: Heinrich Kesslern, 1699).

27 Jörg Bracken, 'Vom Veneto in der Norden', Bauen nach der Natur - Palladio. Die Erben Palladios in Nordeuropa. Museum für Hamburgische Geschichte (Hamburg: Hatje Cantz Verlag, 1997), 20

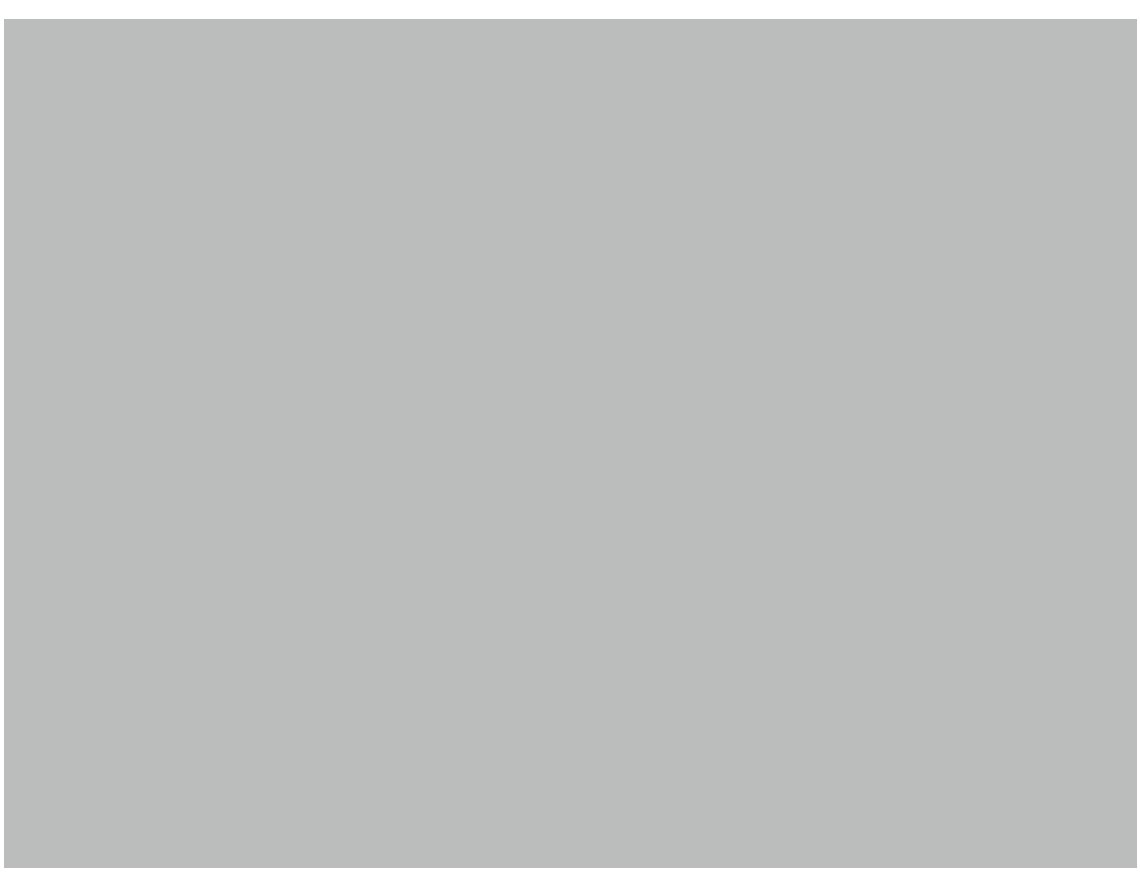

Fig. 1. Peter the Great's house in Narva. Facade and floor plans, 1797. Russian State Military Archive [Rossiiskii gosudarstvennyi voennyi arkhiv, RGIA], 349.19.4686.

principles that have dominated residential architecture in Northern Europe, including Tallinn, since the 17th century. ${ }^{28}$

Soon after arriving in Russia, Trezzini was sent on a business trip to Riga and Narva, where the eastern and western gates of the city were built according to his drawings, and which the tsar demanded be based on the triumphal arches of the Roman emperors. ${ }^{29}$ Trezzini's name is also associated with the reconstruction of St John's Church in Narva into the Orthodox Church of the Transfiguration of our Lord. ${ }^{30}$ Most probably his works included Peter I palace in Narva,

28 Juhan Maiste, 'Das Wohnhaus in Tallinn in der Schwedenzeit', Kunst und Architektur im Baltikum in Schwedenzeit. Acta Universitatis Stockholmiensis. Studi Baltica Stockholmiensia, 12 (1993).

29 Yurij M. Ovsiannikov, Domenico Trezzini (Leningrad: Iskusstvo, 1988), 31-32.

30 Oleg Kotšenovski, Narva, gradostroitelnoje razvitie i arhitektura (Tallinn: Valgus, 1991), 93. 


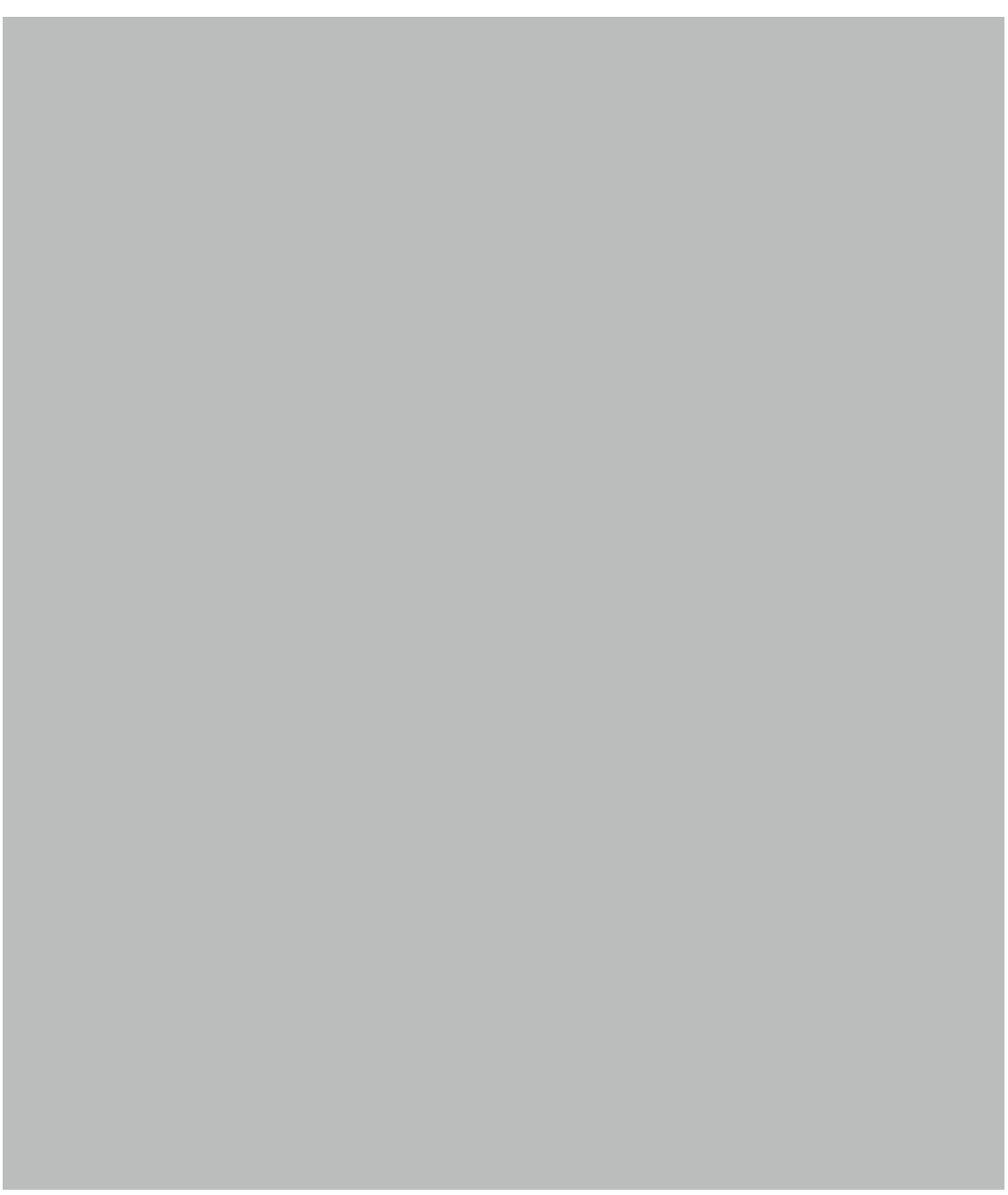

Fig. 2. Peter the Great's house in Narva. Pre-World War II photo. National Heritage Board archives.

which was rebuilt in 1708 from two 17th century residences. ${ }^{31}$ While the prior appearance of the buildings was preserved on the city side, the riverside facade was redesigned, and decorated with a balcony

31 Sten Karling, Narva. Eine Baugeschichtliche Untersuchung (Stockholm: Wahlsbröm und Widstrand, 1936), 204.

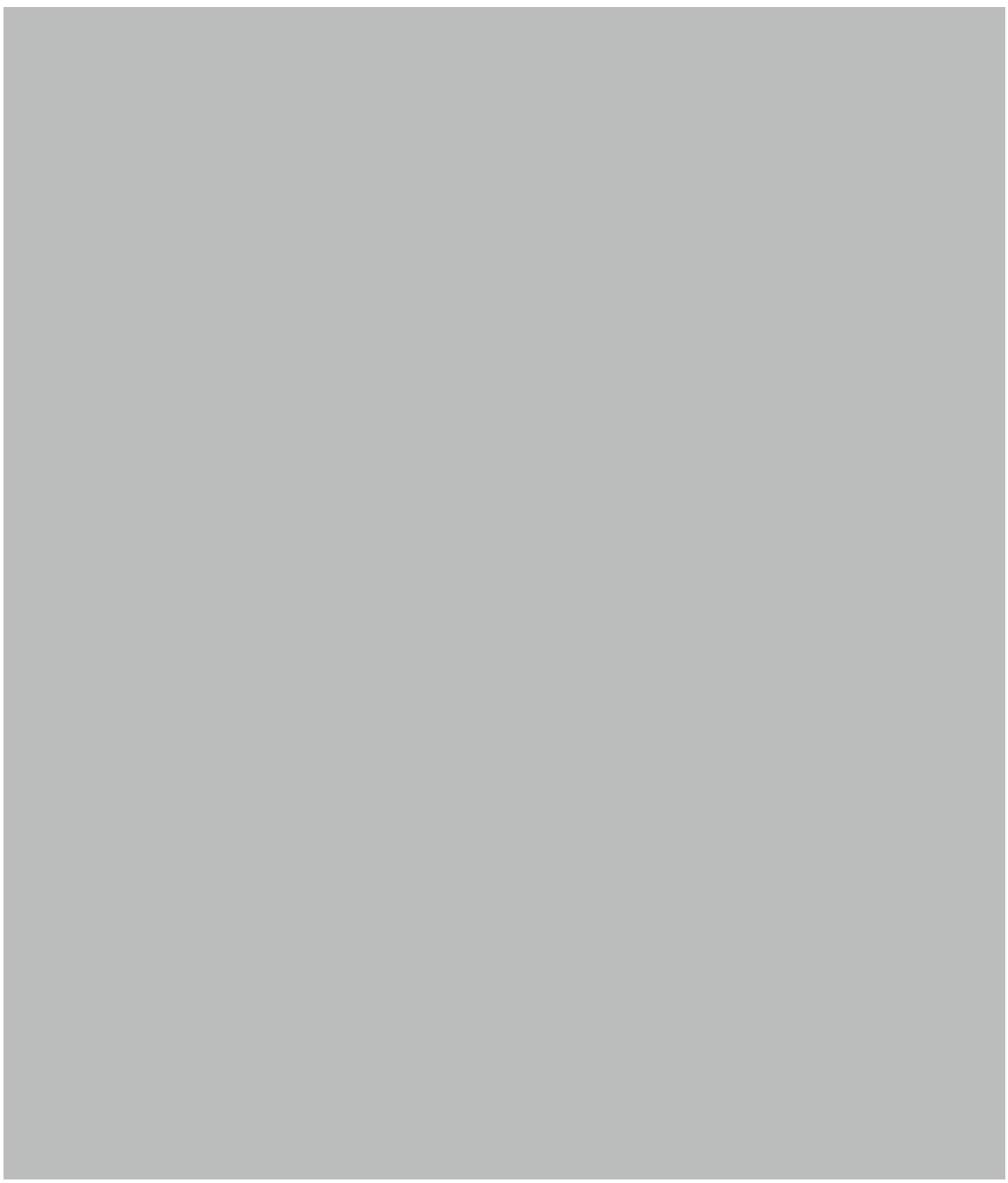

Fig. 3. Peter the Great's house in Narva. Vestibule in 1939. Carl Sarap, Vana Narva (Tallinn Kultuurkoondis, 1939), 72 .

supported by two Italian-style Tuscan columns. A long bridge led from the building to the river port. ${ }^{32}$

In many ways Trezzini was the right person for fulfilling Peter the Great's commissions. In addition to the monumental projects,

32 Kotšenovski, Narva, 97 


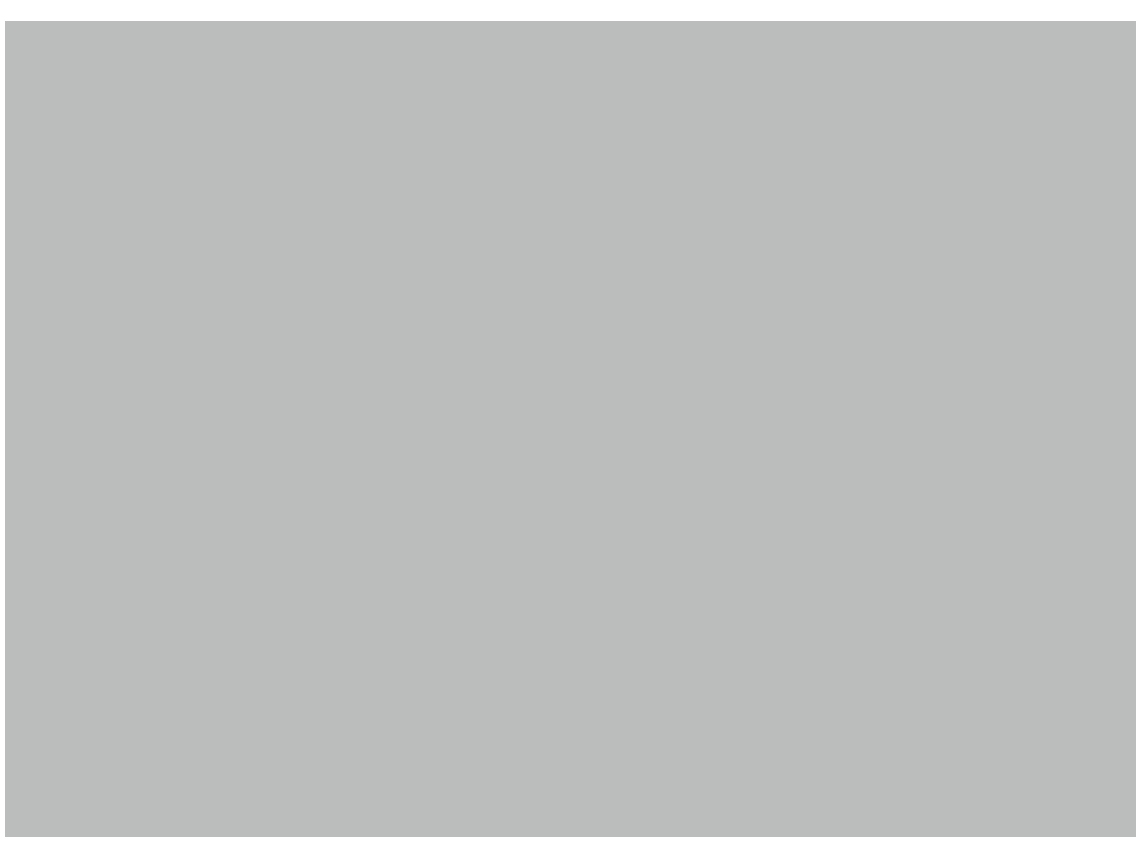

Fig. 4. Peter the Great's house in Narva. Bedroom. Hudozhestvennye sokrovishcha Rossii, T. 3 (St Petersburg, 1908), 58.

the architect's assignments included developing a new scheme for the capital. Model projects (obraztsovye mazanki) were completed for the development of Vasilyevsky Island as well for the whole city, which in many ways, were based on the ideas of Sebastiano Serlio. ${ }^{33}$ The same examples were most probably used by the auxiliary building planned for Kadriorg: the architect's house, greenhouses, stables, sauna, kitchen building, etc. ${ }^{34}$ Which opinion is supported by the fact, that after Michetti's departure from Russia in 1723, the supervision of his work in Kadriorg was taken over by Trezzini's assistant Mikhail Zemtsov. ${ }^{35}$

33 Sergej S. Ožegov, Tipovoe i povtornoe stroitel'stvo v Rossii v XVIII-XIX vekach (Moscow: Strojizdat, 1984), 13.

34 In 1750, Johann Georg Teichert, the local building master prepared drawings for the renovation of the auxiliary buildings of the Kadriorg Palace ensemble. The set of drawings is stored in the Tallinn City Museum [Tallinna Linnamuuseum, TLM], 9283, 15-21.

35 Mai Lumiste, 'Lossi ja pargi ehituskunstiline iseloomustus', Kadriorg: loss ja park (Tallinn: Valgus, 1988), 29ff.

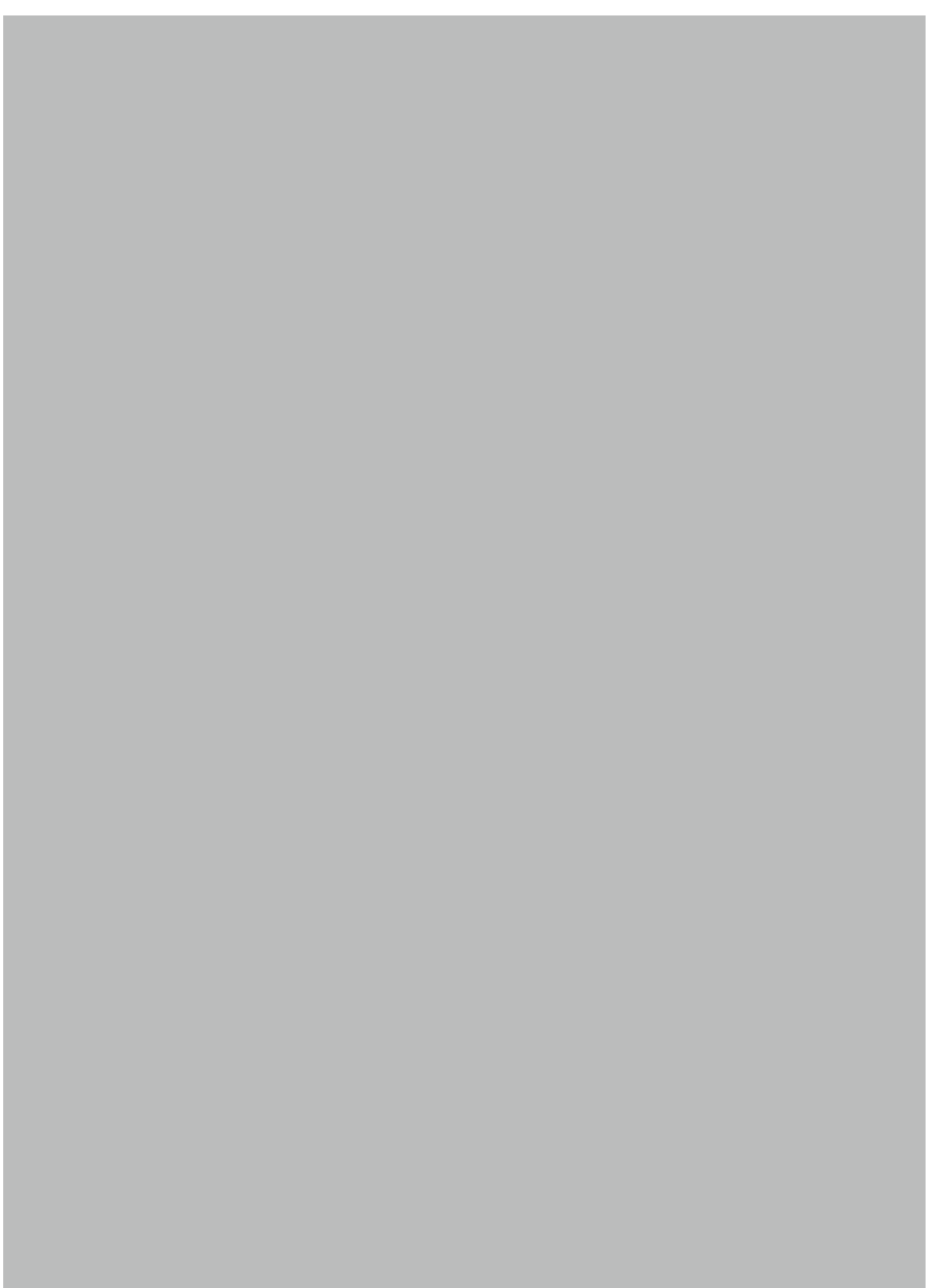

Fig. 5. Peter the Great's house in Narva. Ceiling painting. Hudozhestvennye sokrovishcha Rossii, T. 3 (St Petersburg, 1908), 64.

Thus, it is more than likely that Trezzini was commissioned to design the emperor's town palace in the farthest northwest corner of Tallinn's Old Town. The location was very suitable - a view of 

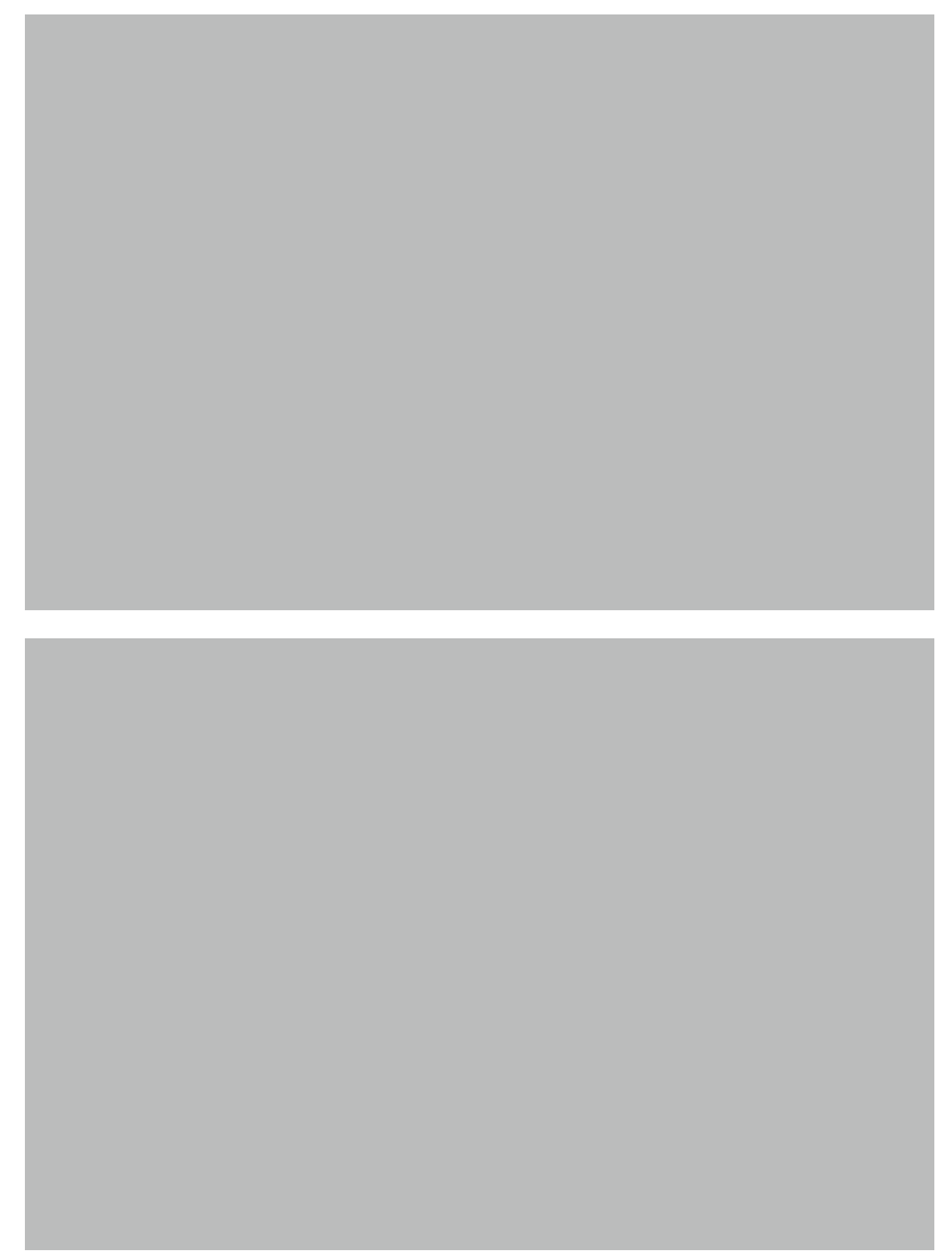

Fig. 6. Peter the Great's city palace in Tallinn. Facade. Drawing by Johann Georg Teichert, 1750s. Tallinn City Museum.

Fig. 7. Peter the Great's city palace in Tallinn. Cross-section. Drawing by Johann Georg Teichert, 1750s. Tallinn City Museum.
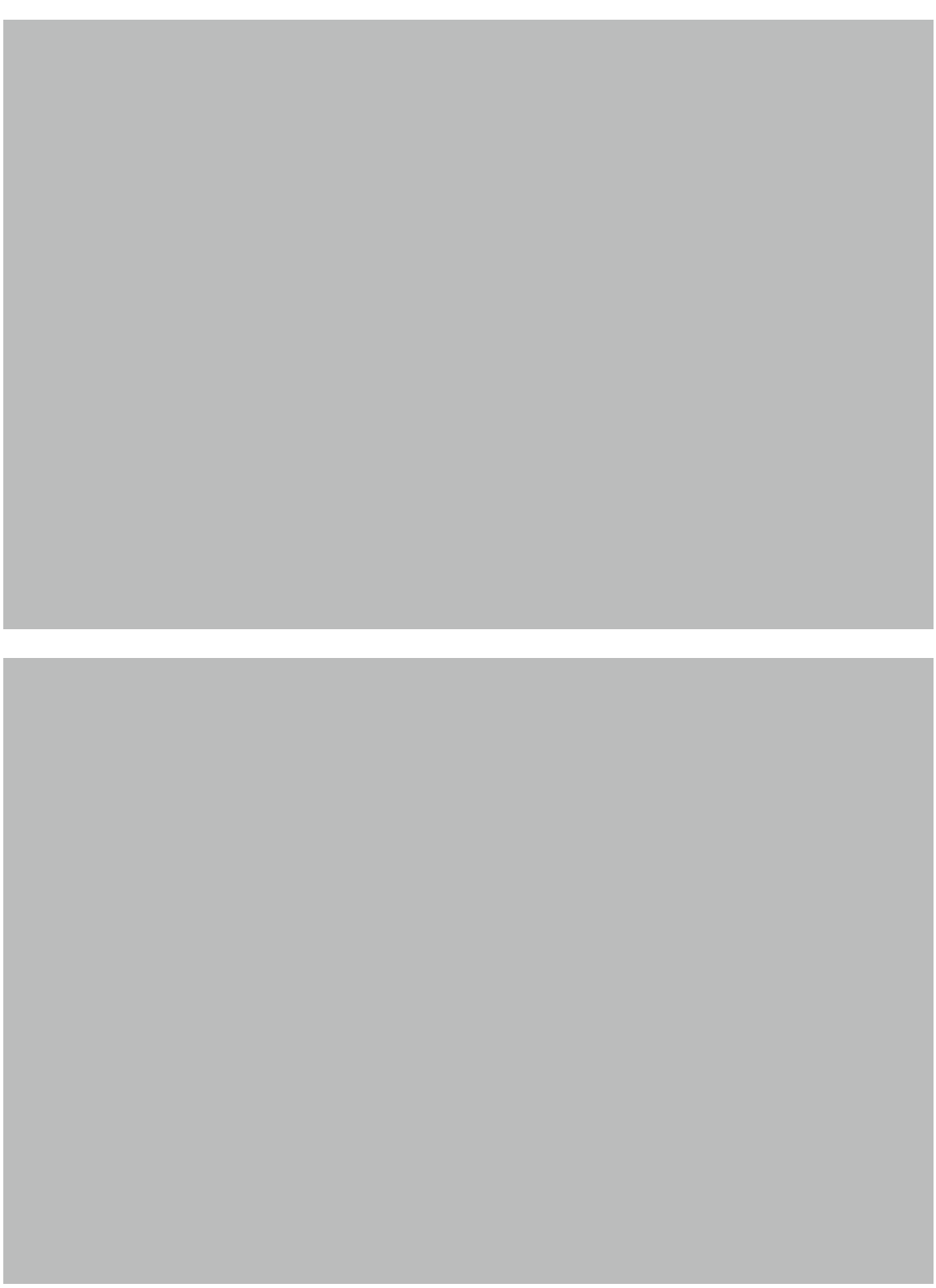

Fig. 8. Floor plan of Peter the Great's city palace. Drawing by Johann Georg Teichert 1750s. Tallinn City Museum.

Fig. 9. Floor plan of Peter the Great's city palace. Drawing by Johann Georg Teichert, 1750s. Tallinn City Museum. 


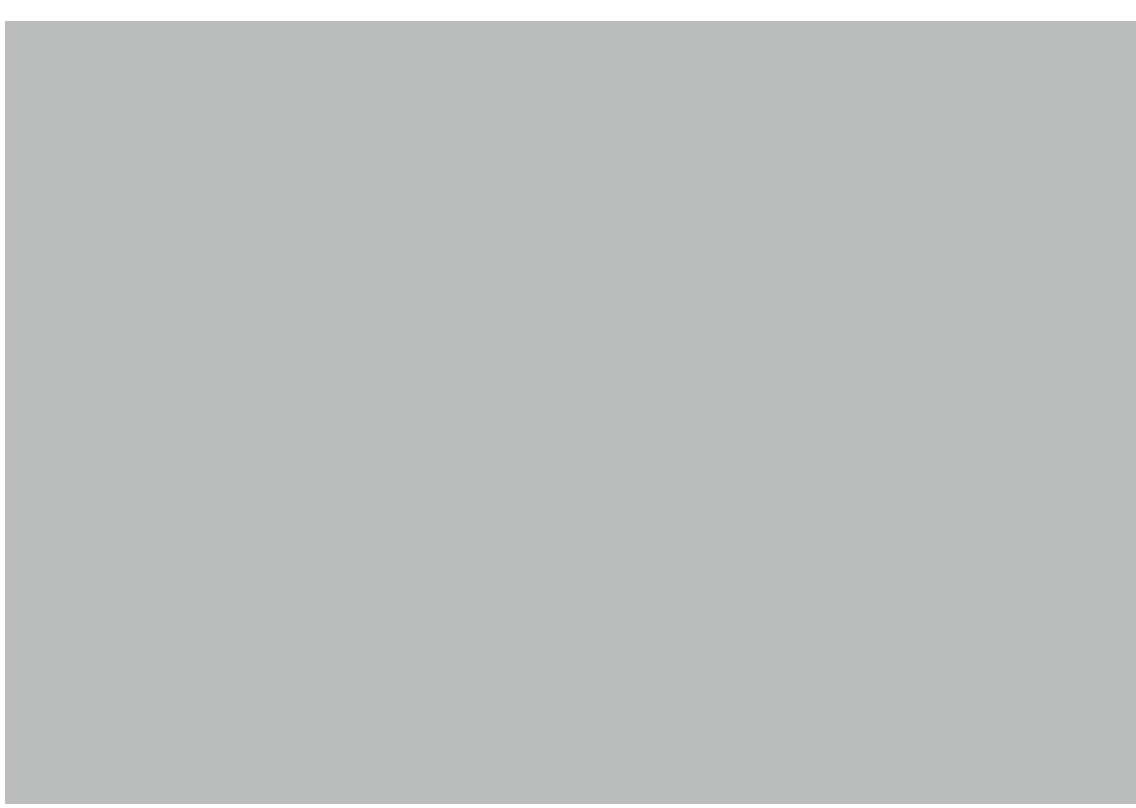

Fig. 10. Floor plan of Peter the Great's city palace. Drawing by Johann Georg Teichert, 1750s. Tallinn City Museum.

the port and the sea was visible from the windows. The property, which had been left ownerless during the war, was transferred to the state in 1712. In 1713, the two medieval houses were replaced by an imposing three-story building made of bricks fired locally in the Kopli brickyard. According Mai Lumiste, the architect of Peter the Great's town palace was none other than Domenico Trezzini. ${ }^{36}$ It would be difficult to imagine that anyone else could have fulfilled a commission from the tsar in 1712-1713. When building Peter the Great's summer palace on the banks of Neva River, Trezzini shared the assignment with Andreas Schlüter, the architect and sculptor from Berlin, who arrived in St Petersburg in 1713. Although the town palace in Tallinn has later been subsequently rebuilt, ${ }^{37}$ we can get idea of its original architecture from the drawings of the local building master Johann Georg Teichert from the 1750s. ${ }^{38}$ The cube-like building was replaced with an elaborate interpretation of architectural forms. Compared other citizens' houses in the town, the building was significantly larger, and its volume is emphasised by the high mansard roof, which had been domesticated in Germany and Scandinavia based on French models from the 17th century. Compared to the Italian examples, they placed greater emphasis on the articulation of the building's mass. The wings project off the central structure (corps de logis), thereby creating a cour d'honneur in the front. Two light-filled stories with formal rooms rise atop the vaulted ground floor. Unlike the architectural idea of the era, the entrance to the building is not located on the central axis, but in contradiction to the laws of symmetry, has been moved to a side street (Tolli Street), instead of being locating on one of the town's main streets (Lai Street). The most imposing rooms along with a vestibule and a grand staircase that extends through all three floors are also located in this wing.

Despite the 'style errors', Peter the Great's town palace can be compared to the palaces that were designed by Trezzini for Peter the Great and the members of his retinue in St Petersburg, including Trezzini's house for distinguished people (dom dlja imenityh ljudei). ${ }^{39}$ And again, an exception to the axial symmetry is traceable to the local character of Tallinn. As an element derived from Serlio and used by Palladio, the access to the courtyard is provided by a vaulted passageway. After all, the construction was taking place on the old narrow streets and a tightly packed urban landscape. Apparently, the finishing work dragged on until 1716, when the Tallinn commander Wilhelm van Delden was obliged to write: 'The local town palace

37 In 1756, a complete renovation of the building was planned: the ceilings, which were partially rotten, were to be renewed, new fireplaces and stoves built, and windows glazed. On June 29th, the palace caught on fire from fireworks, and fell into ruins along with the area behind the Horse Mill and Wulfard tower, as well as the tower of the Grea Coastal Gate. The building stood in ruins for the next 30 years. Most of the buildings walls were also destroyed; and when the new building was constructed, in 1786 only the northern walls of the ground floor were reused. See: https://linnaarhiiv.wordpress com/2017/06/29/peetripaeva-tulekahju/ [accessed 20.02.2018].

38 The plans for second floor of the building, the cross-section and drawings of the roof trusses have survived. TLM, 9283, 8-14.

39 See: Grabar, Istoriya Russkogo Iskusstva, 31. 


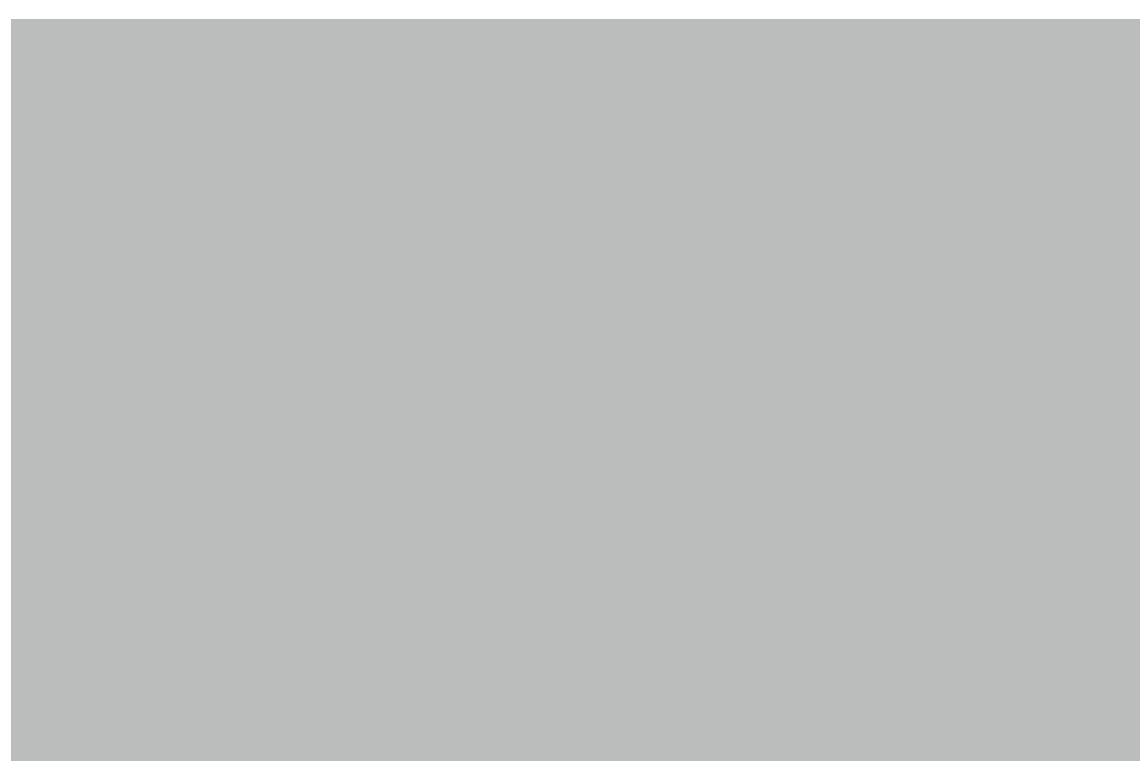

Fig. 11. Hiiu-Suuremõisa Manor (1755-1760). Photo: Juhan Maiste, 2000

belonging to the tsar lacks stoves in many of the chambers (palatõ) and halls, there are no coverings on the walls or interior furnishings, and chairs and other furniture are missing as well. ${ }^{40}$

In Tallinn, Peter the Great's palace is undoubtedly a modern building that was several 'style steps ahead of its time. The tsar's building activities marked the beginning of a new epoch and brought together modern solutions. In fact, the ideas characteristic of Peter the Great's palace did not become established in the Baltic provinces until the mid-18th century. One of the earliest examples to be mentioned in Estonia was the Hiiu-Suuremõisa Manor (17551772) that belonged to the Stenbock family. The canon derived from Italian-French architecture did not become domesticated in the work of the German building masters until the last decade of the 18th century when the nobility, which had by then recovered from the war and economic recession, started to build new manor ensembles throughout the country.

40 Kuuskemaa, Peeter I ja Katariina I Tallinnas, 12.

\section{THE SPIRIT OF THE RUSSIAN ORTHODOX \\ ARCHITECTURE.}

\section{CUPOLAS AND DOMES}

In the architectural tradition of Northern Europe, the dome does not often occur. It is a slightly foreign motif, which seldom found a place in post-Reformation sacral architecture and which, as such, was related more to aesthetic and form-related considerations then to deeper religious ideas. The dome signified Rome, be it old or new Rome, and was associated with the rebirth of the idea of a church with a central dome that started with Leonardo, Bramante and Antonio da Sangallo during the Italian Renaissance, and the Islamic architecture based on the Hagia Sophia basilica. ${ }^{41}$ As two different points of departure, these two parallel lines sketch the etymology of the domed church, which via numerous loans and mediators, have more points of contact than one might assume based on their religious doctrines. ${ }^{42}$ Domed architecture as a concept of space and architectural form crosses confessional boundaries; by containing information on the domination of the visual and aesthetic essence, as it has been explained in this anthology by Georgy Smirnov, by combining the idea of a central church in Russian Orthodox architecture with the artistic and stylistic impulses of Western Europe.

The renewed emphasis of the idea of a house of worship as Solomon's temple in the 17th century can be treated as an updating of a separate architectural theme, which as the basic principle of all architecture, highlighted the cosmopolitan idea of a world that combined the two traditional forms in church architecture, i.e. Längsbasilika und Zentralkirche. ${ }^{43}$ In many ways, the aesthetics inherited from the Renaissance era crossed religious boundaries. The architectural tracts became the intermediaries between two worlds the Catholic South and Protestant North - which brought the idea of a domed churches to places with new geographical coordinates. The

41 Gülru Necipoğlu, The Age of Sinan. Architectural Culture in the Ottoman Empire (London: Reaktion Books, 2005), 82ff.

42 Georg Satzinger, 'Die Baugeschichte von Neu-St. Peter', Barock im Vatikan. Kunst und Kultur im Rom der Päpste II. 1572-1676, ed. by Jutta Frings. Ausstellungskatalog (Leipzig: Seemann, 2005), 45ff.

43 Christian Norberg-Schulz, Spätbarock und Rokoko. Weltgeschichte der Architektur (Stuttgart: Deutsche Verlags-Anstalt, 1985), 38. 


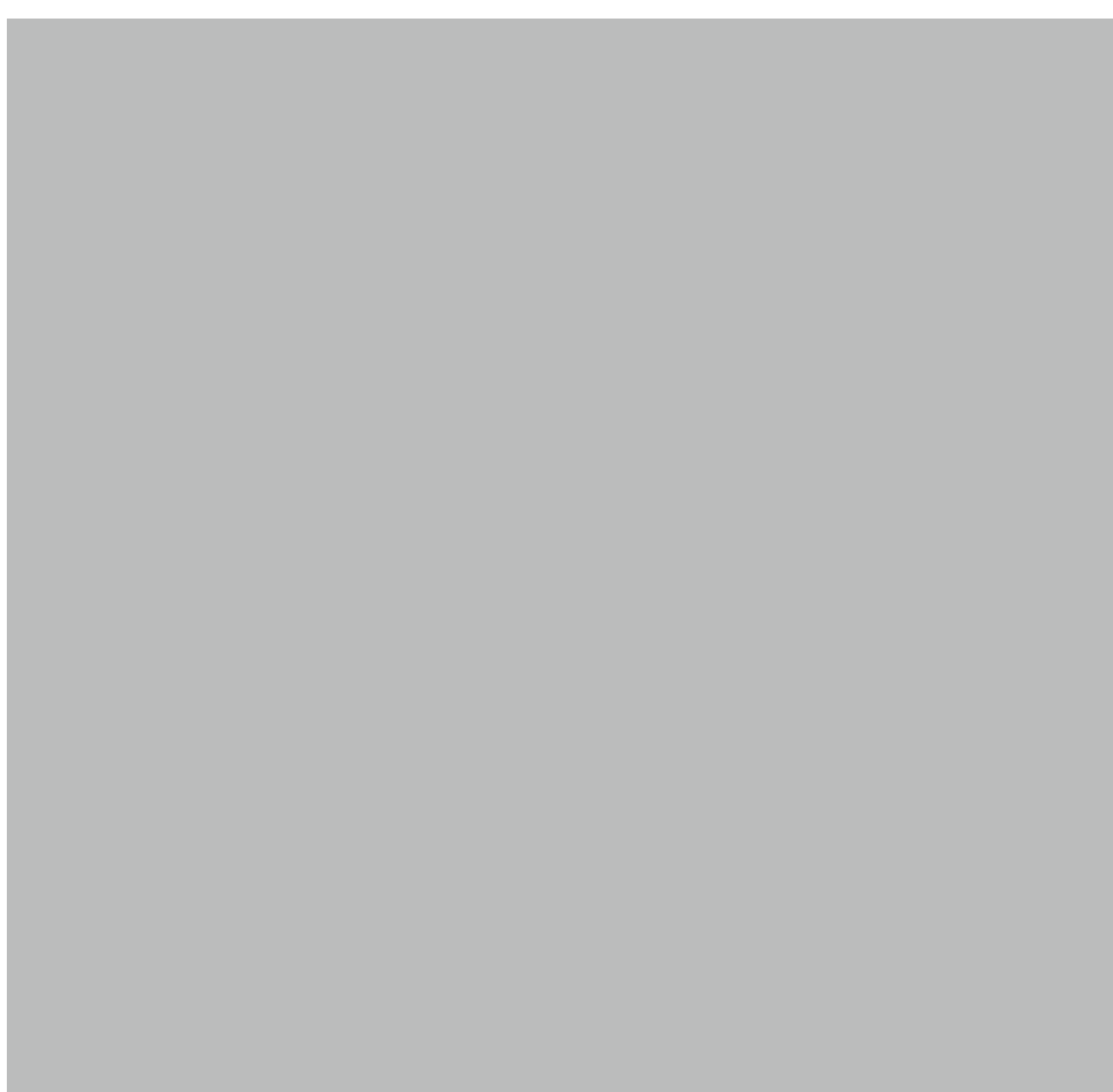

Fig. 12. Tallinn town fortifications in 1798. RGVIA, 3-26-964, 14.

grandest examples of the era became St Catherine's Church (begun in 1656) and Ulrika Eleonora Church (begun in 1673) in Stockholm. In their general concept, these two were very far from belonging to the mainstream; on the broader scale, their architectural solution is symbolic of the age, but, at the same time, is exclusive in many ways. Concurrently, the impact of Jean de Vallée and St Catherine's Church reached as far as Schlesien, where under the direction of Martin Franz, an architect from Tallinn, the Hirschberg Gnadenkirche (Grace

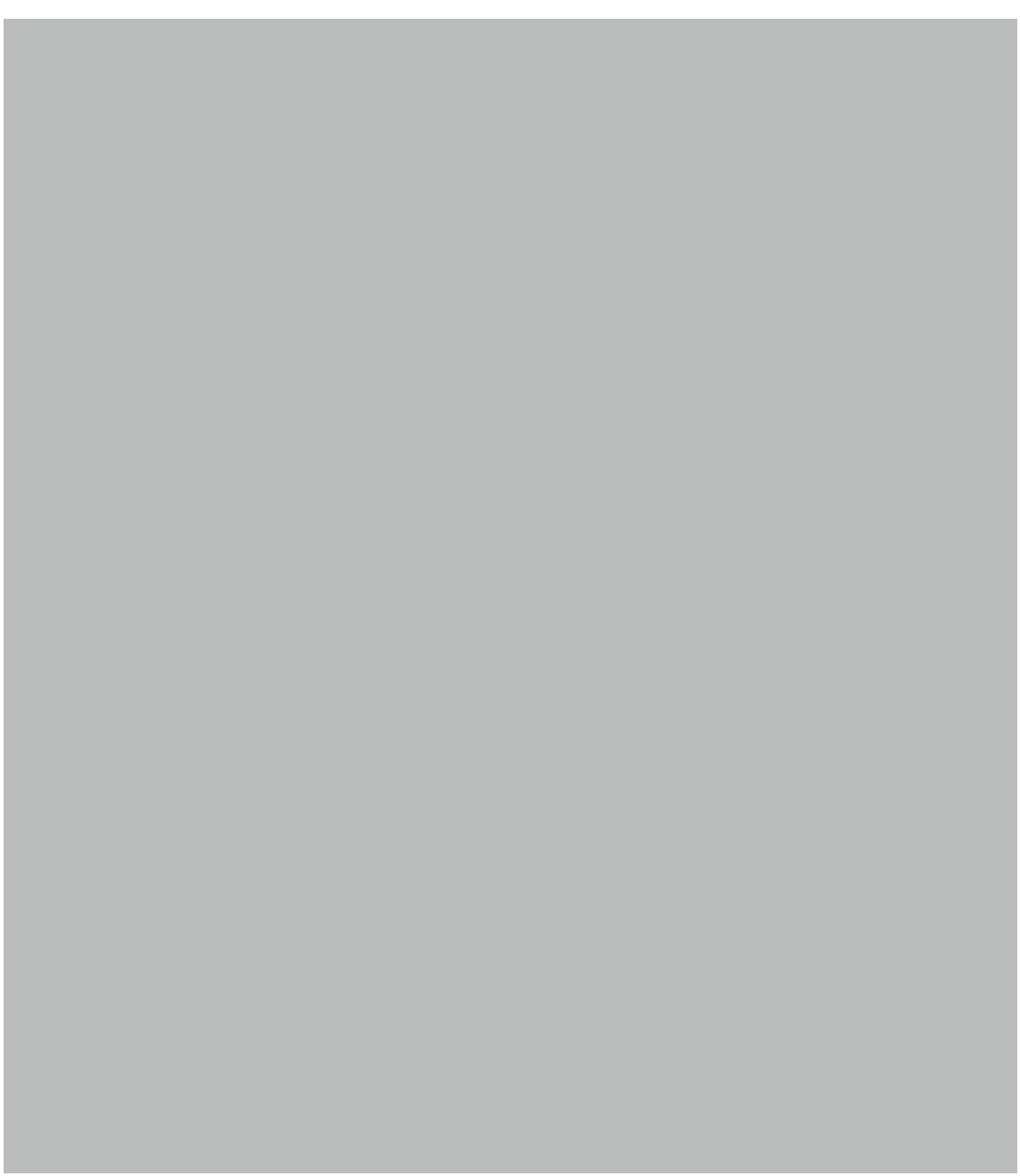

Fig. 13. Finnish Church in Narva's New Town. Facade. Drawing by Erik Dahlberg, 1683. Krigsarkiv, Stockholm. Reproduction from: Sten Karling, Narva. Eine baugeschichtliche Untersuchung (Stockholm: Wahlström \& Widstrand, 1936).

Church) was built. ${ }^{44}$ Almost the only example of a central church in Estonia before the invasion of Russian church architecture in the 18th century, was the Finnish Church in Narva (1683, destroyed), which was designed by Erik Dahlberg, the Governor-General of Livonia, fortification engineer and architect.

44 Karling, Narva, 307. 


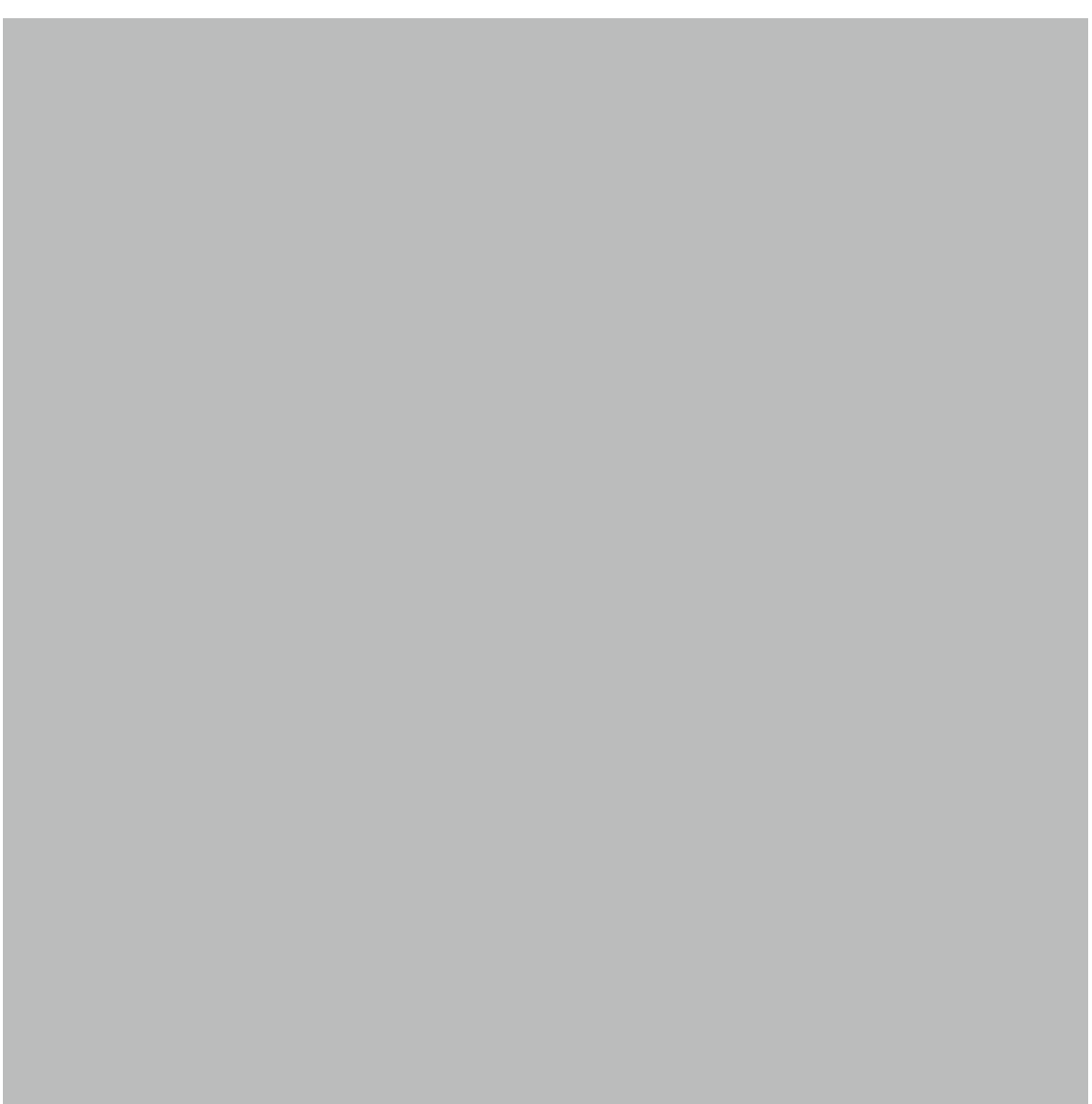

Fig. 14. Finnish Church in Narva's New Town. Floor plan. Drawing by Erik Dahlberg, 1683. Krigsarkiv, Stockholm. Reproduction from: Sten Karling, Narva. Eine baugeschichtliche Untersuchung (Stockholm: Wahlström \& Widstrand, 1936).

Something that is valid in a metropolis may not be as meaningful in the provinces. In the Baltic territories, where the Orthodox religion was based on a political programme, the domed church was a monumental manifestation and extension of power. All the Orthodox churches built in Estonia during the 18th century, and most of those built in the 19th century, were completed on the orders of the central authorities. If in the motherland, the objective of the central authorities was to change the appearance of the cities that were indigenously Russian to be more European, then in the western provinces of the empire, the wish was to mark the presence of the

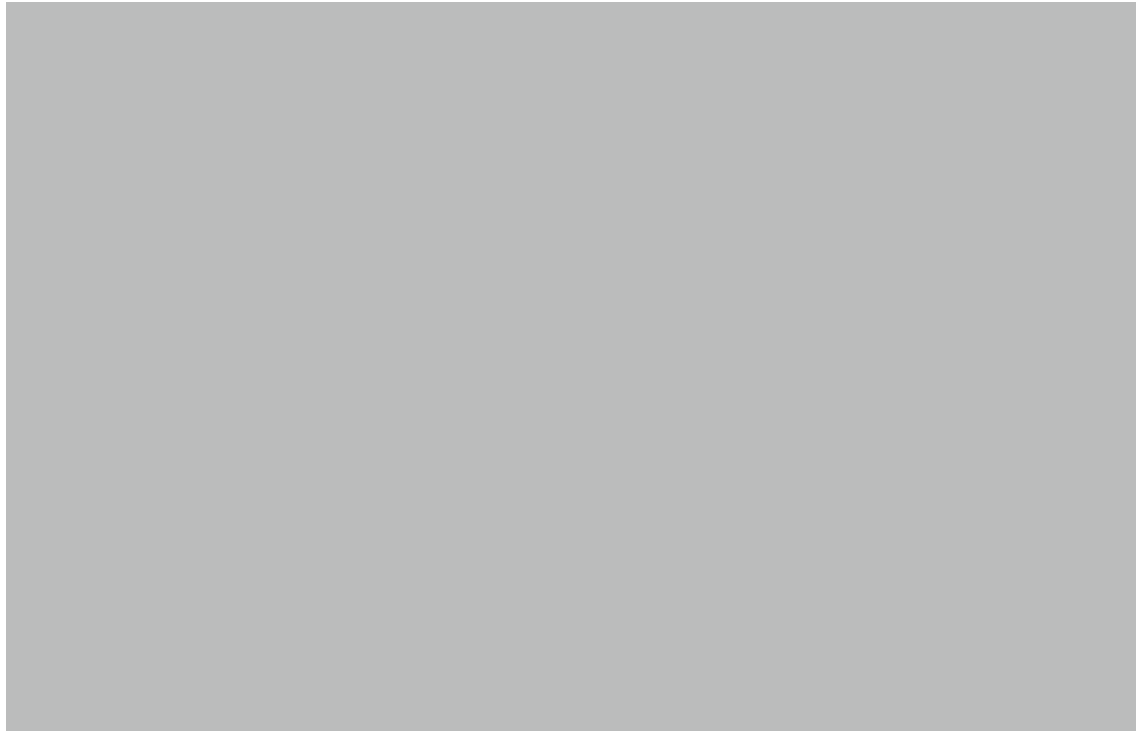

Fig. 15. Design of domed church. Drawing by Johann Wilhelm Krause, 31 May 1820 RGIA, 733.98.258, 3.

empire, and give the city skylines a more universal and Orthodoxoriented appearance. The dome indicated an identity, which along with the aesthetic aims, was meant to emphasise the authority and continuity of Orthodox Russia. On more broader scale the new type of five-domed churches, which made itself visible in the time of Elizabeth Petrovna, is apparent in Pärnu's St Elizabeth's Church (architect Pyotr Yegorov, project 1763) as well the Dormition of the Mother of God Cathedral in Tartu (Paul Speckle, 1776-1783) and later in the various projects for Tallinn's St Nicholas Church and the Church of the Transfiguration of our Lord. ${ }^{45}$

A hundred years had to pass after the Great Northern War before the dome found its place on the Parnassus of Baltic architecture, by becoming the creative guide for the tastes of the local patrons and architect's projects. It was the iconic model for the large Pantheontype domed church in Tartu, which was designed by Johann Wilhelm

45 Georgy Smirnov, Linda Lainvoo, 'Vene õigeusu kirikud Eestis', Eesti kunsti ajalugu 3 (Tallinn: Eesti Kunstiakadeemia, 2017), 326ff. 


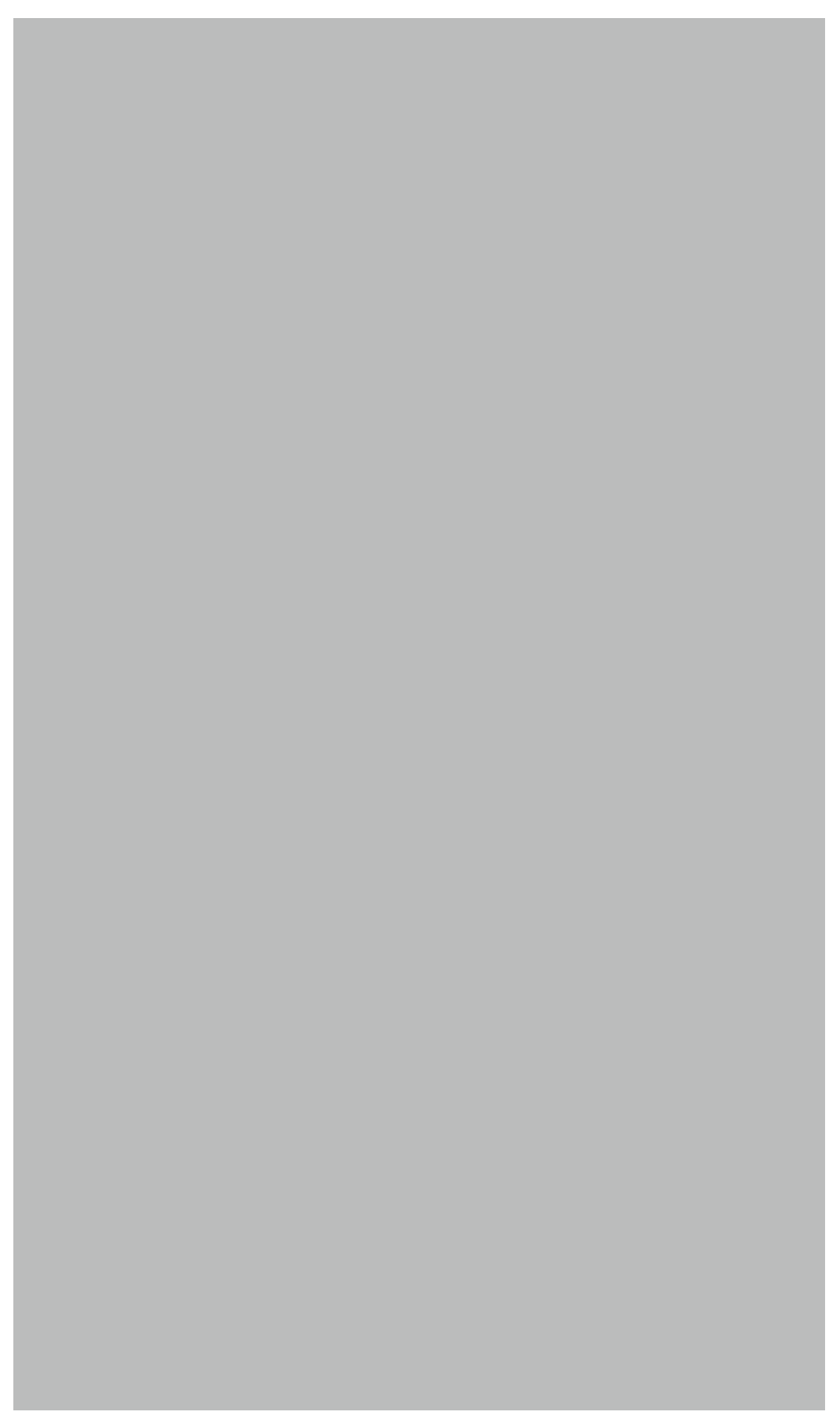

Fig. 16. Les Invalides in Paris. Leonhard Christoph Sturm, Vollständige Anweisung, alle Arten von regularen Pracht-Gebäuden (1754).

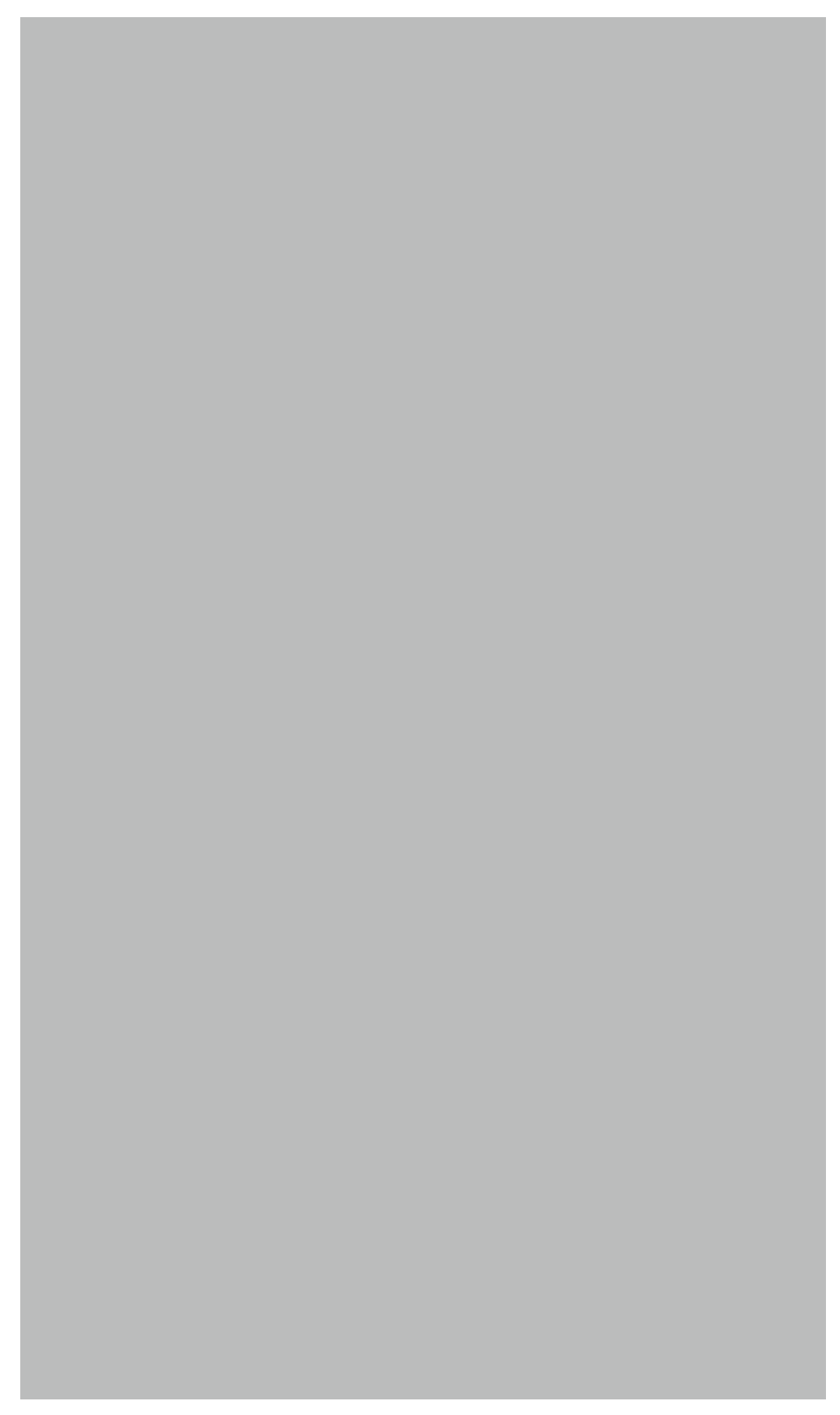

Fig. 17. Plans for a Protestant church. Leonhard Christoph Sturm, Vollständige Anweisung alle Arten von regularen Pracht-Gebäuden (1754). 


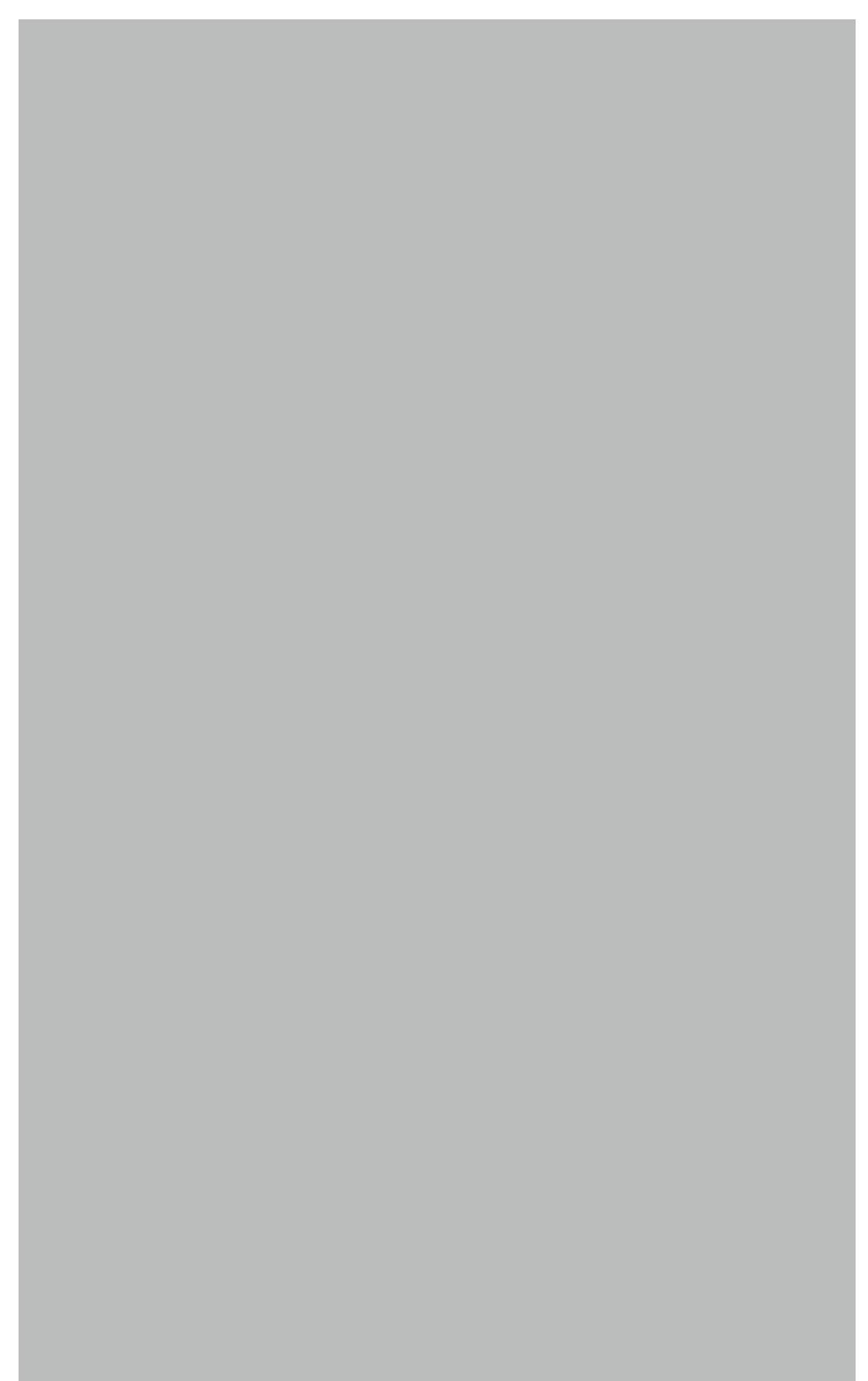

Fig. 18. Domed church with columned porticos. Christian Ludwig Stieglitz, Encyklopädie der bürgerlichen Baukunst, Vol. 3 (1797), Plate 9.
Krause, the architect of the University of Tartu. A long and intriguing prelude led up to the idea of a domed church. Already in 1803, Krause presented the idea of utilising the ruins of the ancient cathedral on the Toomemägi (Cathedral Hill), whereby the church and library would be brought under the same roof. However, the architect's ideas remained on paper. And it was not until 1820, that Krause was able to return to his idea. There were two different projects on the table at the same time. According to the first, the church would be built in the ruins of the cathedral despite all the inherent difficulties, while the second called for it to be built in the lower town. A discussion broke out among the professors, which already in those days was called 'pluralistic'. The majority of the council opposed the ideas of the restoration that would have been too expensive. Another solution was to build the church in the lower town. The first drawing for a smalltown church (Kleinen Stadt Kirche) with a triangle shape was completed on 29 May $1820^{46}$ as had been recommended by Leonhard Christoph Sturm, in his drawings for a Protestant church (Protestierende Kirche). ${ }^{47}$ A similar model of a triangular church was also included in the architectural encyclopaedia of Christian Ludwig Stieglitz. ${ }^{48}$

At the same time Krause was experimenting with the cupola form. Recently, another collection of drawings for the church in Tartu were found in the Russian State Archive of Early Acts. ${ }^{49}$ Krause's idea was based on the drawings of Val-de-Grâce and Sorbonne by Leonhard Christoph Sturm, which were based on the model of St Peter's Basilica in Rome. In addition we can find the drawings of Invalidendom..$^{50}$ However, as Sturm explained, the Italian and French solutions were not as good as the similar solutions in Germany: ...ohne ich der dem nirgend an dem Französischen Zimmerweck etwas gefunden, das mit den

46 RA, EAA, 2100, 11, 132, 20

47 Leonhard Christoph Sturm, Vollständige Anweisung, alle Arten von regularen der Pracht-Gebäuden nach gewissen Reguln zu erfinden, auszutheilen und auszuzieren, benebs (Aursure in Verlegung Jer sechs Ordno Chritoph Sturm from the year of 1754 .

48 Christian Ludwig Stieglitz, Encyklopädie der bürgerlichen Baukunst, Bd. 3 (Leipzig, 1797), Taf. 9.

49 Central State Historical Archive of St Petersburg [Tsentralnyi gosudarstvennyi istoricheskii arkhiv Sankt-Peterburga, TsGIA SPb], 733-96-258. The author of the article thanks Georgy Smirnov for directing the author's attention to these materials.

50 Sturm, Vollständige Anweisung, alle Arten von regularen der Pracht-Gebäuden nach gewissen Reguln zu erfinden (1754), Tab I, X. 
Teutchen vergleichen, noch weniger vorgezogen zu verdient hätte, will ich dabey nicht aufhalten, sondern lieber nach dem Teutschen Fundament der Verbindung der Crempel auf eine grössere Kuppel vorstellen, daraus man die Ganze Sach gründlich wird verstehen lernen. ${ }^{51}$

In his theory Sturm makes the difference between the old Roman tradition and new religions based on the theories of Nikolai Goldmann. Goldmann hat den Unterschied unter den Kirchen vor das Publikum und den vor verschieden Religionen die von der Römischen Kirche ausgegangen sind. ... In der Römischen Kirche wird vornehmlich darauf gesehen das viel Kapellen mit kleinen Altären können gemacht werden und das unten auf der Erde viel Volks stehen könne. Hingegen in der Protestantischen Kirchen sieht man vornehmlich darauf das eine grosse Menge einen einigen Prediger wohl sehen und höret können. ... Daher man auch die Römisch - Katholischen Tempel nicht leichtlich mit darinnen ausgetheileten vielen Säulen und Pfeilern verderben kan, dahingegen die Protestantische Kirche den Platz in der Kirche so viel immer möglich ist ganz frey haben wollen. ... Wenn Goldmann der alten Kirche gedencket, versehet er die alten Tempel der Heyden, deren Beschreibung bey dem Vitruvio sonderlich sehr schön in der Französischen Edition des Herrn Perraults zu finden. ${ }^{52}$

The entire space of the university church by Krause is built up in a form of an amphitheatre. The columns supporting the roof separate the spaces for the parterre and the loges for the honoured seniors' (Logen für Honoratioren, besond. Senioren). The church has three entrances, of which the central one is planned as a portico with six columns, or as Krause called it a prostylos. A separate entrance on the eastern side is located behind the altar, providing a way to enter the most important space - the zone for the 'priest'. Along the chancel stairs behind the altar, the pastor was raised even higher. During the design process Krause made several alterations. On one of the drawings, the area underneath the dome is called the Geräumiger Platz vor dem Altar. A remarkable place is assigned to the baptismal

51 Sturm, Vollständige Anweisung, alle Arten von regularen der Pracht-Gebäuden nach gewissen Reguln zu erfinden (1754), 20.

52 Leonhard Christoph Sturm, Vollständige Anweisung, alle Arten von Kirchen wohl anzugehen: worinnen 1. Nic. Goldmanns Anweisung und drey Exempel angefuhret, und mit Anmerckungen eräutert. 2. Ausführlicher von Römisch-Catholischen Kirchen, und insonderheit. 3. Von den kunstlichen Bau der grossen Kuppeln. 4. Von Protestantischen Kirchen gehandel, mit fünff neuen Inventionen von jenen, und sechs von diesen der Praxi gemäss erkläret, und in 22 saubern Kupfer-Platten appliciret wird (Augsburg: Jeremiae Wolffens, 1718). font (Taufstein). Krause specifies separate zones for men and women on the ground floor and balcony, following ancient traditions, and borrowing ideas from the masonic references that were popular among the university professors.

In his stylistic approach, Krause had taken decisive steps in the direction from the baroque classicism of the 17th century to the Neoclassicism inspired by the spirit of the Enlightenment. The facade of the church resembles the university's main building (which may also have originally been borrowed from Stieglitz's drawings). ${ }^{53}$ Like the university, the front facade of the church is marked by six Doric columns. In this meaning the architect is travelling along well-worn paths. The sphere of his erudition includes the depths of all the Greco-Roman classics represented in the new editions of Vitruvius as well as the new wave of architecture represented by JacquesGermain Soufflot's Panthéon in Paris. As a matter of fact, having studied German architectural publications, Krause had become familiar with the new trends developed at the École des BeauxArts, including the drawings of Marie-Joseph Peyre's Academy of St Luke in Rome and the visionary fantasies of Nicolas Le Camus de Mézières Halle au Bleds. ${ }^{54}$

The form of the dome as an architectural element was already used by Krause for the university observatory and anatomical theatre, where the architect was inspired by the cupola pavilions represented in Christian Cay Lorenz Hirschfeld's ‘Theory of Garden architecture'..$^{55}$ Still, the construction of large cupola church formed a new and different challenge. Magnificent dome churches may have glimmered in his memory. Along with architectural treatises, inspiration was provided by the great buildings in Berlin and St

53 Christian Ludwig Stieglitz, Zeichnungen Aus Der Schönen Baukunst Oder Darstellung Idealischer Und Ausgeführter Gebäude Mit Ihren Grund-Und Aufrissen: Auf 100 Kupfertafeln (Leipzig, 1798), Taf. 1-3.

54 The building was completed between 1763 and 1767. In Germany the drawing appeared for the first time in Nicolas Le Camus de Mézières, 'Von der Übereinstimmung der Baukunst mit unsern Empfindungen', Allgemeines Magazin fur die burgerliche Baukunst, Schmidt, Der Bürgerliche Baumeister oder Versuch eines Unterrichts der Baulustige (Gotha: Selbstverlag 1790-1799). Krause's drawings of St Luke's Academy are undated (TÜR 3852) he Halle aux Blés dates from 1803, and became the model for university's bathhouse as well as the manège.

55 Christian Cay Lorenz Hirschfeld, Theorie der Gartenkunst, Bd. I-V (Leipzig: M. G. Weidmanns Erben und Reich, 1779-1785). All five luxurious volumes in leather were present at the University library in Tartu and used by Krause. 
Petersburg, which Krause had seen on his travels: among them St Hedwig's Cathedral by Johann Boumann in Berlin and Kazan Cathedral by Andrey Voronikhin in St Petersburg. At the same time when preparing the drawings for the huge cupola church in the city, which was already being called the Athens on Emajõgi (Embach) River, Krause faced a completely new task. The dome, which is set atop a tambour, is disproportionally large, and the massiveness of the dome exceeds the load-bearing ability of its supports. It is very difficult to distinguish which concrete examples Krause followed. Beside the great metropolises of the era, we can recognise the influence of the local projects that were fulfilled mostly by architects from St Petersburg; for example, the similarities between Krause's vision and one of the designs of the orthodox church of Nicholas in Tallinn by Luigi Rusca. ${ }^{56}$

One is also reminded of the designs of the architectural competition for the Cathedral of Christ the Saviour in Moscow organised in honour of the victory over Napoleon in 1812. The participants of the event, which was supported by Tsar Alexander I, included the most prominent architects of the time in Russia: Giacomo Quarenghi, Andrey Voronikhin, Ivan Starov, as well as Andrei Melnikov ${ }^{57}$, the person, who was responsible for the adding the dome to the old Church of the Transfiguration of our Lord in Tallinn. In one way or in another, Krause may have been familiar with the Moscow projects, what were quite well-known and most probably had an impact on the tastes in Tartu. A mediator between Tartu and the wider world was Carl Ludwig Engel, who had good relations with the emperor and fulfilled his assignments, not only in Helsinki, but also in the Russian capitals. ${ }^{58}$

The first plans for the Helsinki Cathedral (St Nicholas' Church) designed by Engel were completed a year before Krause's plans for his domed church. It is possible, that Krause and Engels already became acquainted when Engel was working as the Tallinn town architect (1809-1814). ${ }^{59}$ In a letter from 1822 to Carl Herrlich, a friend

56 Smirnov, Lainvoo, 'Vene õigeusu kirikud Eestis', 337.

57 Elena Lebedeva, Hram Hrista Spasitelja (St Petersburg: Mednyy vsadnik, 2011).

58 Henrik Lilius, Carl Ludwig Engel 1778-1840. Näyttely Helsingin Tuomiokirkkon kryptassa (Helsinki: [Opetusministeriö], 1990).

59 Helmi Üprus, 'Carl Ludwig Engel Tallinnas', Töid kunstiteaduse ja -kriitika alalt, 3 (Tallinn: Kunst, 1980), 154-195. from his youth, Engel says, 'In the spring, I received a letter from Struve [Professor of Astronomy Friedrich Georg Wilhelm von Struve - J. M.] in Tartu - Lieven, the university curator, had given him the assignment of renovating the ruins of the "old Russian church" (Dome cathedral) into a university church, which would include new halls and have a high Gothic-style tower. It seems that Professor Krause, who has built all the other university buildings, is now too old and sick to be able to direct such a large construction project. ${ }^{\prime 60}$

However, Engel refused the offer. In 1829, a year after Krause's death, David Visconti, an architect from St Petersburg was invited to Tartu ${ }^{61}$ But unfortunately, nothing came of the idea to build a church building that time either. In 1835, Moritz Heinrich Jacobi, who had studied in Göttingen and Königsberg became Professor of Architecture at the university, and he prepared the plans and budget for constructing a domed church. ${ }^{62}$ But once more, the church was not built. It was only after that, when Karl Rathaus, the university architect, presented his plans to the university in 1851 that things started to move. And a small, building in the spirit of Berlin's 'modern' architecture was finally built behind the university's main building.

\section{GERMAN ETHOS AND RUSSIAN STYLE IN THE ARCHITECTURE OF THE NOBILITY}

The Great Northern War resulted in serious war wounds not only in the towns but also in the countryside. The first to start recovery was the nobility, who after the Swedish reduction policy gained their manors back. The ownership of Maardu (Maart) and Lagedi (Laakt) nearby Tallinn was transferred to Peter's close friend Prince Alexander Menshikov. ${ }^{63}$ Maardu Manor was renamed Fürstenhof. In southern Estonia, a very large property that covered the entire Räpina (Rappin) parish went to Gerhard Johann von Löwenwolde,

60 C. L. Engel to C. Herrlich (22.12.1822). Carl Ludvig Engel, Kirjeet, comp. by Nils Erik Wickberg (Helsinki: Helsinki-Seura, 1989), 177.

61 Johannes Frey, 'Ein alter Plan zum Wiederaufbau des Dorpater Domes: Nach den Akten des Universitäts-Archivs', Sitzungsberichte der Gelehrten Estnischen Gesellschaft zu Dorpat 1910 (Dorpat: K. Mattiesen, 1911)

62 Niina Raid, Tartu ehitusmeistrid 17. sajandist kuni 19. sajandi keskpaigani (Tallinn: Eesti NSV Riiklik Ajaloo Keskarhiiv, Tartu Riiklik Ülikool, 1987), 87.

63 Ants Hein, 'Mõisaarhitektuur 18. sajandi algul ja keskpaigas', Eesti kunsti ajalugu, 1520-1770, ed. by Krista Kodres (Tallinn: Eesti Kunstiakadeemia, 2017), 232. 


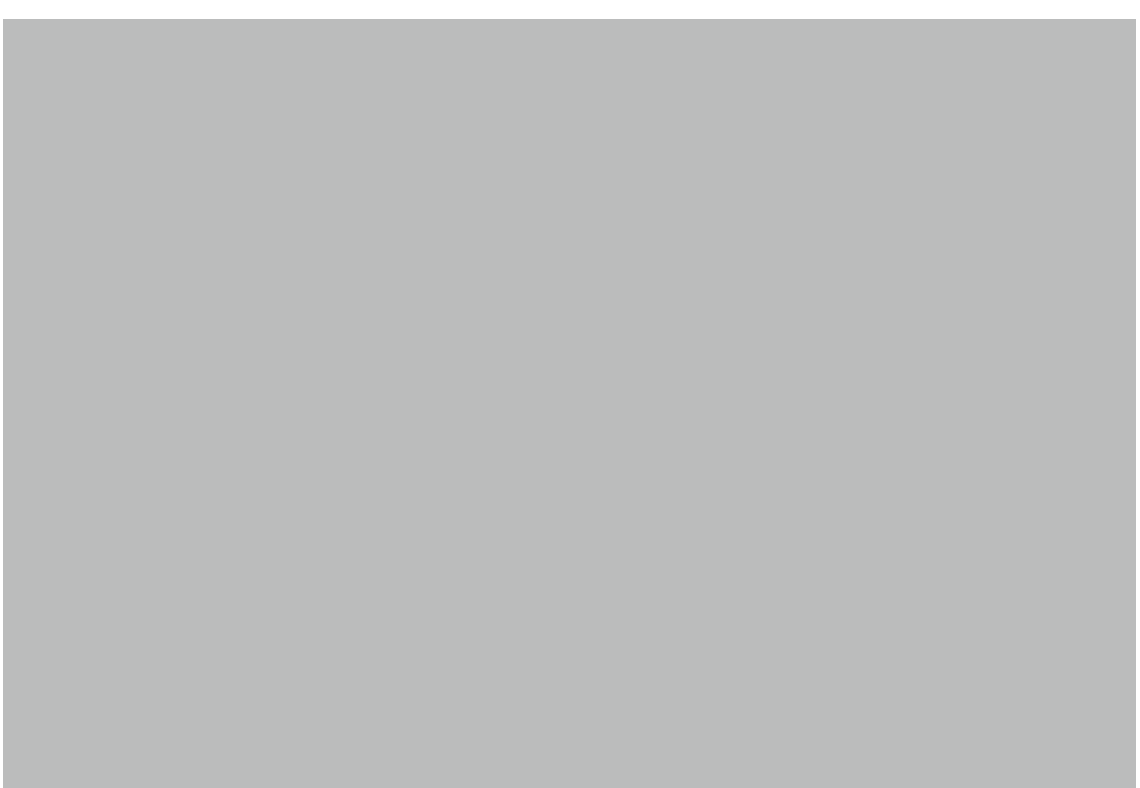

Fig. 19. Main building of Õisu Manor (1760s). Reconstructed in the early 19th century. Photo: Juhan Maiste, 2016

who together with Johann Gerhard / Reinhold von Patkul had opposed the fiscal policies of Charles XI of Sweden, and helped to form an anti-Swedish coalition. In 1731, after his splendid wedding celebrations in Mazstraupe (Klein-Roop; Lielstraupe on Gross-Roop) in southern Livonia (Latvia today), von Löwenwolde's son Karl Gustav von Löwenwolde made a stop in Räpina on his way back to St Petersburg. Some years later an impressive manorial centre was established at his estate along with one of the largest paper mills in Europe, which supplied the capital with the paper necessary for the state chancellery. ${ }^{64}$ The manor was built by Johann Georg Keiser, who is remembered in local legends as the Russian tsar (not survived). ${ }^{65}$

64 Õie Utter, Leo Utter, Räpina paberivabrik. Peatükke arenguloost Teise maailmasõjani (Räpina: Räpina Paberivabrik, 2014), 18.

65 The Keiser name is very widespread in the Netherlands and northern Germany architects and artists of this name are well-known. It is possible that Keiser arrived in Estonia via St Petersburg.
During the 1730s, impressive ensembles were built elsewhere in South-Estonia: at the Saare (Saarenhof) Manor, in Luua (Ludenhof) and in Ahja (Aya), which Catherine I gifted to the widow of pastor Johann Ernst Glück of Alūksne (Marienburg), under whose roof the young girl had once sought shelter. The Glücks' son-in-law, François Guillemot de Villebois, had the Baroque manor house built in Ahja. ${ }^{66}$ Or here's another example. At the initiative of Friedrich Wilhelm von Sivers, the son of Admiral Peter von Sivers of the Russian Navy, a magnificent ensemble was built in Õisu (Euseküll) in the 1760s: the building ensemble in the Palladian style is joined to a French-style park, the models for which may have come from the tsar's residences, the Peterhof and Tsarskoye Selo. In addition to the regular park, an English-style park was also established in Õisu by 1782 . By the time Alexander I visited Õisu in 1809, a columned portico with spacious granite staircase with two Italian style marble Goddesses had been added to the manor house, which gave the house the appearance that was similar to Sheremetev's Kuskovo Palace in Moscow.

One of the most unique manor houses was completed in Vääna (Faehna) in 1784, which, with its stretched-out floor plan and two rotunda-shaped domed structures on the ends of the building, was a counterpart to a new type of villa that developed in Rome and northern Italy - in Veneto, Piedmont and Lombardy - in the early $18^{\text {th }}$ century ${ }^{67}$ According to reports written about a hundred years later, the palace was built by an Italian architect. The owner of the manor Otto Christian von Stackelberg and his wife, who was the daughter of Peter III's chamber master Gottschalck von Dücker, ${ }^{68}$ 'had travelled to Italy, where they had convinced an architect and sculptor to come with them to Russia, so they could decorate their manor according to their taste.... The building was given a flat roof in the Italian style - which was decorated with statutes hewn of the sandstone from the Vääna sea shore. However, in the autumn storms and snow of the Estonian winters soon forced the owner to remove

66 Hein, 'Mõisaarhitektuur 18. sajandi algul ja keskpaigas', 235

67 Caroline Vincenti, Fabio Benzi, Roberto Schezen, Römische Paläste (München Orbis, 2003), 26ff. Jung 'Architektur und Stadt in Italien zwischen Frühbarock und hbarock und

68 Natalie von Stackelberg, Otto Magnus von Stackelberg: Schilderung seines Lebens und seiner Reisen in Italien und Griechenland (Heidelberg: C. Winters Universitätsbuchhandlung, 


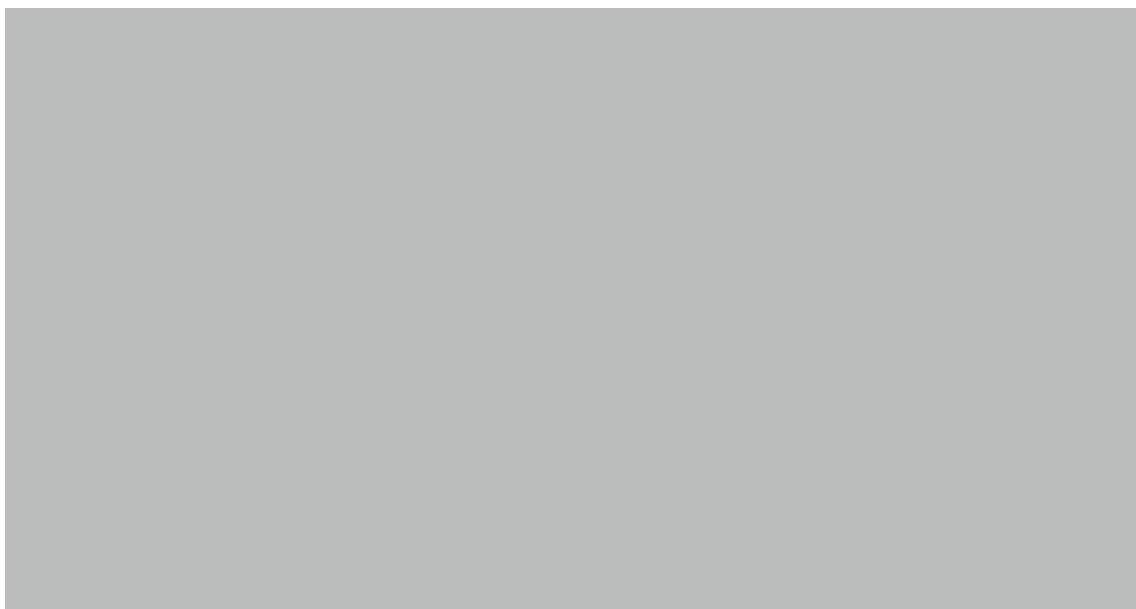

Fig. 20. Vääna Manor (1780s). After Wilhelm Siegfried Stavenhagen. Steel engraving, 1860s

the statues and build a weatherproof roof. ${ }^{\prime 69}$ One possibility is that the Italian architect was still not invited during the journey, but invited from St Petersburg - Italian Antonio Rinaldi, who has started his career with Luigi Vanvitelli in Rome, moved over to Russia and was responsible for building the 'private villa' (sobstvennaja datša, 1762-1774) for Catherine the Great (on the drawings of the Chinese Palace there are many details similar to Stackelberg's palace (a stretched-out building, spacious main staircase, balustrades decorated with sculptures). ${ }^{70}$ Vääna was famous because of its art collections: 'Der einzige Sohn der kammerherrn von Dücker, der schon als Jüngling eine Reise nach Italien unternahm, erwerb dort eine Sammlung von 140 wertvollen Gemälden, eine zahlreiche Menge trefflicher Kupfertische, Gemmen, Münzen und sonstige Kunstgegenstände; ferner eine interessante Sammlung verschiedener Holzarten, Muscheln und Mineralien. ${ }^{71}$ To what later were added the collections of Otto Magnus von Stackelberg, the

69 Wilhelm Siegfried Stavenhagen, Album Baltischer Ansichten (Mitau: Stavenhagen; Leipzig: Reybers, 1861-1867)

70 Julietta A. Kyuchariants, Antonio Rinaldi (Leningrad: Stroiizdat, 1984), 51.

71 Stavenhagen, Album Baltischer Ansichten, Bd. 3 (1867). famous archaeologist and Entdecker of Greece..$^{72}$ Already in 1787, the art collections of Vääna were mentioned by August Wilhelm Hupel. ${ }^{73}$

The allure of the metropolis fed one's imagination and inspired one to copy. In 1783 August Wilhelm Hupel wrote about the Russian palaces in Paullust (Pavlovsk) and Marienthal located two versts from each other seven versts from Tsarskoje Selo: Auf einer artigen natürlichen Anhöhe, an deren Fuss ein aus verschiedenen Quellen und Springbrunnen entstehendes Wasserfliest, liegt das Schloss ${ }^{74}$ nebst den Gebäuden für die Offizianten, in einem schön gepflasterten und mit einem eisernen Gitter umgebenen Hof; sämtlich nehmen sie einen mässigen Raum ein. Denn da die Grossfürstliche Familie dies Schloss selten länger als auf einige Stunden besucht, so ist es nur klein, und von zwei Stockwerken, beide ländlich und einfach möblirt: Das untere ist für die beiden jungen Grossfürsten, und deren Suite, bestimmt. Das Gebäude hat ein plattes Dach und auf selbigem eine Art von sinesischen [chinese - J. M.] Lusthaus mit einem Tisch und Stühlen, wo man unter dem angebrachten Obdach auch mitten im Regen der freien Luft geniessen kan: Hier findet man eine sehr reizende Aussicht. Gleich an den Hof stösst ein englischer Garten, wo noch sehr viel wird angelegt werden: etliche Ruinen von alten verfallenen Schlössern, ländliche Brücken u.d.g. sind bereits darin angebracht. Nicht weit vom Wasser bauet man an dem Tempel der Freundschaft, zu welchem der Römische Kaiser, da Er unter dem Namen eines Grafen von Falkenstein in St Peterburg war, den Grundstein legen hast. - In Wasser befindet sich kleine Inseln, auf welchem Grotten, Einsiedlerhütten, Springbrunnen u. d. g. abwechseln. - Auf diesem Lustschloss geniesst die Grossfürstin im eigentlichen Verstand das Landleben; daher werden auch hier allerle ländliche Thiere, Federvieh u.d. g. unterhalten. - Das schönste, und was hier die meiste Bewunderung erregt, ist die sogenannte auf der dem Palais gegenüberstehenden und bereits mit einigen Anlagen versehenen Anhöhe, befindliche Bauerhütte, die neben einem gewöhnliche Kohlgarten liegt, unsern Dorfhäusern ganz ähnlich sieht, ein von Rauch schwarze Wände

72 Juta Keevaliik, 'Otto Magnus von Stackelberg', Eesti kunsti ajalugu, 3 (Tallinn: Eesti Kunstiakadeemia, 2017), 147ff.

73 August Wilhelm Hupel, 'Der in Lief- und Ehstland zunehmende gute Geschmack', Nordische Miscellaneen, 13-14 (Riga: Johann Friedrich Hartknoch, 1787), 496.

74 The Pavlovsk palace was built by Charles Cameron between 1782-1786, who also designed the huge English stylepark with numerous temples, colonnades, bridges, and statues. The Temple of Friendship was the first building in Pavlovsk, followed by the main palace. Constrained financially, Paul and Maria closely watched Cameron's progress and regularly curbed his far-reaching, expensive plans. Between 1786 and 178 Cameron's duties in Pavlovsk passed over to Vincenzo Brenna. 
hat. Ohne Anführer würde der Fremde diese Hüte gewiss keiner Bobachtung würdigen. ... Von allem lässt sich wegen der doppelten Wand nichts von den innern Schönheiten bemerken und vermuthen. ... Marienthal, steht ebenfals auf einer Anhöhe ${ }^{75}$, und ist wie ein Festung angelegt worden; daher sieht man rings herum kleine mit Kanonen bepflanzte Wälle, und vor der Einfahrt zum Schloss über den Graben eine Zugbrücke. In einiger Entfernung befinden sich an der Anhöhe unter den Bäumen versteckte anmuthige Grotten und kleine Lusthäuser. Mehrere Anlagen werden noch künftig hinzukommen. Dieses Lustschloss wird, weil die Aussicht nicht so schön ist wie zu Paulslust, seltner besucht. Das bey diesem Pawlowski eine Kirche, ingleichen sei Hospital ${ }^{76}$, sollen erbaut werden, haben im abgewichenen Sommer bereits Zeitungen gemeldet. ${ }^{77}$

And Hupel continues elsewhere: 'The good taste that rules elsewhere in the world does not leave anyone cold. A foreigner visiting our country found both good tone and taste after becoming familiar with the city and the noble manors. /---/ Kabala (Kabbal), Võisiku (Woiseck), Põltsamaa Palace (Schloss Oberpahlen) and UuePõltsamaa (Neu Oberpahlen), Pada (Paddas), Voka (Choudleigh), Aseri (Asserien), Aa (Haakhof), Vinni (Finn), Rägavere (Reggafer), Mõdriku (Mödders), Koigi (Koick), Koluvere (Scloss Lohde) have been praised by his princely highness. ${ }^{78}$ According to Johann Christian Petri: '... the noble life in the country manors is organised so charmingly that one can easily forget the city. /---/ As a whole, they live in the splendour, [amid] the fine taste that characterises the nobility elsewhere in the world. /---/ All the necessities - a house, bountiful dining table, company and servants, horse carriages - the rich noblemen have everything, and certainly no less than the ones in Germany. ${ }^{79}$ If the literati and writing intelligentsia, were connected more to Germany and the Enlighted mind of 'Goethe Zeit'; in the case of the nobles, in addition to the time they spent in the German

75 The new Marienthal palace was built later for the wife of Paul I the princess of Württenberg Sophie Dorothee Auguste (Russian Maria Fjodorovna, 1759-1828) according to the plans of Vincenzo Brenna in 1795-1797.

76 The hospidal in Pavlovks was built by Giacomo Quarenghi in 1784

77 August Wilhelm Hupel, 'Kurze Nachrichten, Anekdoten, Sagen und Anfragen' Nordische Miscellaneen, 5-6 (Riga: Johann Friedrich Hartknoch, 1783), 312-313.

78 Hupel, 'Der in Lief- und Ehstland zunehmende gute Geschmack', 487.

79 Johann Christoph Petri, Ehstland und die Ehsten oder historisch-geographisch-statistisches Gemälde von Ehstland, 2. Theil (Gotha: K. W. Ettinger, 1802), 362.

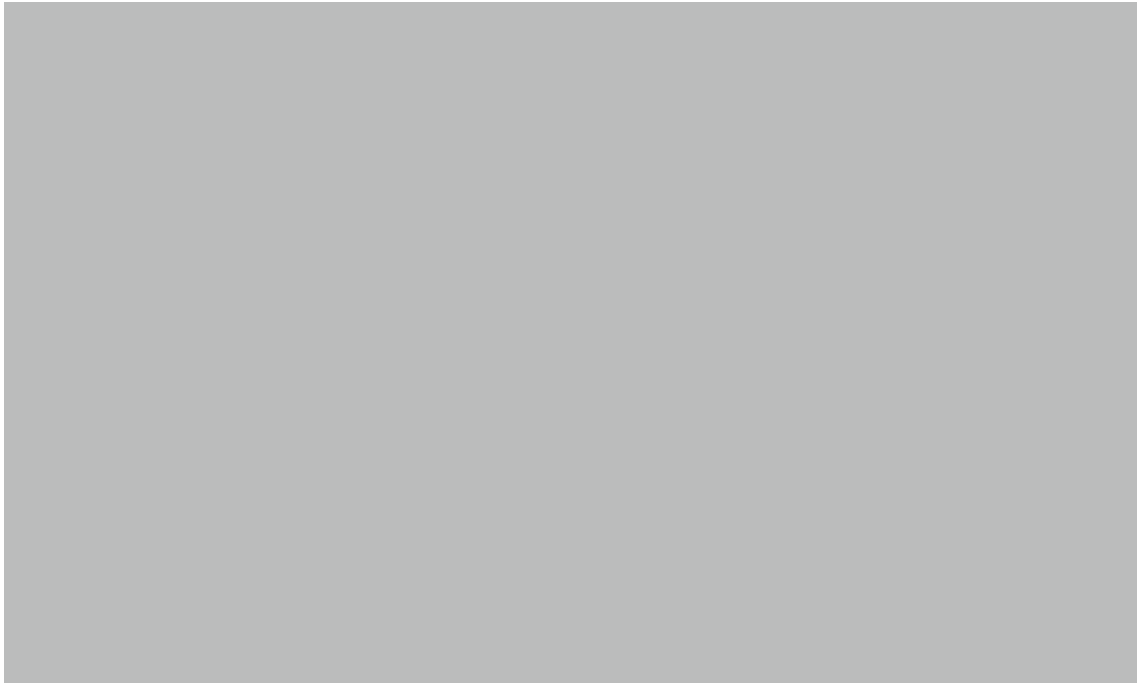

Fig. 21. Mežotne Manor in Courland (1797-1802). Architect Giacomo Quarenghi. Photo Juhan Maiste, 2015.

universities in Göttingen, Halle, Weimar, and somewhat later Berlin - their careers at the court in St Petersburg provided the impetus and model for building the residences in the style that reflected their status in the Russian capitals. French style rose alongside the German one, what replaced the influences of Palladianism of early Neoclassicism with the new reception of Vitruvius ideas. The aim of the nobility was to think more broadly, travel more, become citizens of the world. At a time when Europe was being wracked by Revolution and wars, the nobility turned their estates into 'oases' of the educated mind and artistic splendour. With their powerful columns, domes and Serlio-style 'Venetian' windows, the manor house became a place, where the local meant the universal, and the international was represented by the highest level of architecture.

In Courland, the idea for the architecture of the Mežotne Palace (Mesothen; 1797-1802), which Catherine the Great gifted to her lady-in-waiting Charlotte von Lieven, is based on the ideas of Giacomo Quarenghi. Quarenghi's plans also formed the basis for the construction of the Eleja (Elley) Manor, which belonged to Count Jeannot Medem, the husband of Duke Peter Biron's sister-in-law. 


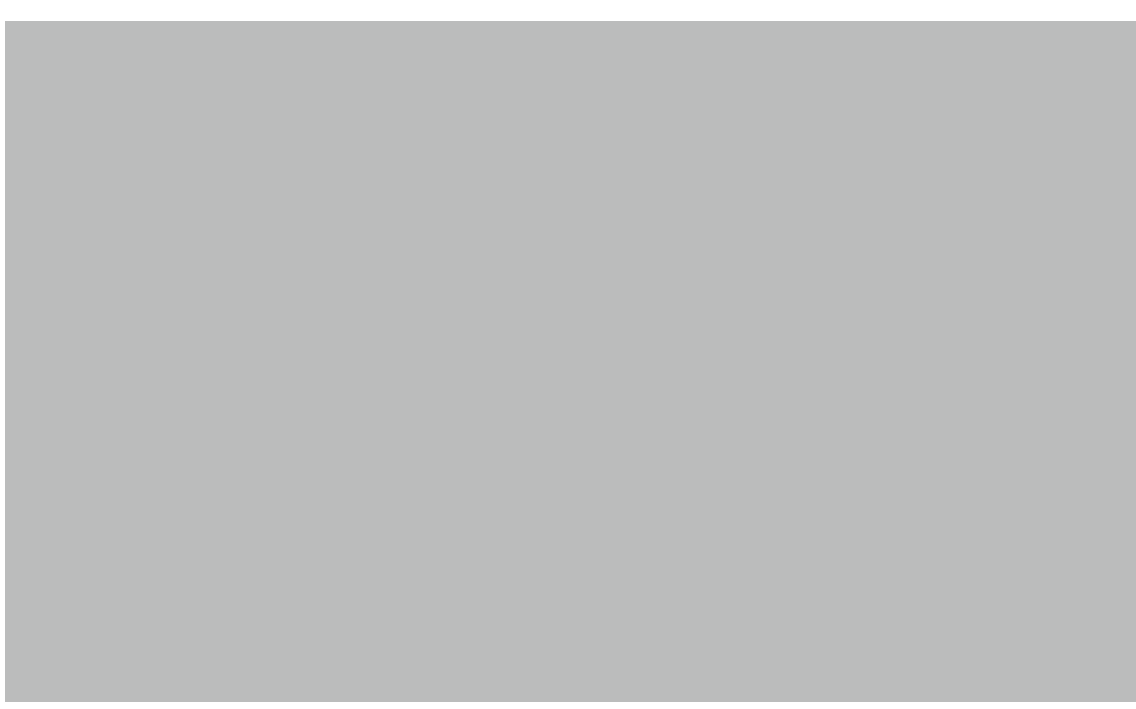

Fig. 22. Aaspere manor house (late 18th - early 19th century). Photo: Juhan Maiste, 2016

In 1797, contributions to the building was made by Carl Friedrich Schinckel, as well as Johann Georg Berlitz, who had come to Courland from Jena and completed the project in 1810. Berlitz's plans were also used for the construction of Kazdanga (Katzdangen; (ca. 1800) Durbe (Durben) near Tukums (1820-1821), Blīdene (Bliden; 1829-1830 and Villa Medem in Jelgava (1835-1836). ${ }^{80}$

In Estonia, the list of manor houses with a St Petersburg orientation starts with Count Otto Magnus von Stackelberg's Pada (Paddas) Manor by Jean Baptiste Vallin de la Mothe, the nephew of Jacques-François Blondel and the 'first neo-classicist' of St Petersburg ${ }^{81}$. Nearby Pada on the postal road from St. Petersburg to Tallinn stands Aaspere (Kattentack) manor, which was acquired in 1785 by the architect and state counsellor Georg Friedrich (Juri Mihhailovich) Veldten - a German by birth. In front of the house with six Doric columns,

80 Imants Lancmanis, 'Schloss Elleja/Elley und die Bautätigkeit des Grafen Jeannot Medem in Kurland', Elejas Pils (Rundāle: Rundāles pils muzejs, 1992), 41ff.

81 August Wilhem Hupel, Topographische Nachrichten von Lief- und Ehstland, Bd. III (Riga: Johann Friedrich Hartknoch, 1782), 476; Vaga, Vene arhitektide ja skulptorite teoseid baroki- ja klassitsismi-ajajärgust Eestis, $9 \mathrm{ff}$. there is a spacious square framed by storehouses and stables, and a view of the cattle herd opens up across the pond..$^{82}$ The Chinesestyle room on the main floor alludes to Veldten's ideas - the architect had designed a similar room for the tsar's residence in Tsarskoje Selo. ${ }^{83}$ Behind the main building the English-style park was laid out with bridges over the ponds and serpentine paths. In addition to the manor ensemble, attention was also payed to the beautiful Käsmu fishing village, which was turned into the summer resort. The sea, the coastal pines and offshore granite boulders speak about a new spirit and the changing tastes. Similar gardens have been designed by Veldten in St Petersburg, for example, for the Betskis' palace, which has been described as follows: 'There is a garden by the house, which includes a library, the owner's study and picture gallery, where there is a large collection of valuable works by Dutch masters. The owner, wearing a smock often walks around the park, accompanied by Count Ernst Johann von Münnich ${ }^{84}$ brother of Field Marshal Burchard Christoph von Münnich, the owner of Luunja (Lunia) manor in Southern Estonia. ${ }^{85}$

Aaspere marks a milestone. Following its example, the residence of Count Stenbock in Kolga was completed between 1800 and $1803 .{ }^{86}$ An impressive columned portico and wings were added to the house, which had already been completed in 1768 . The hall in the northern wing, which was two stories high, was used as a ballroom. This is

82 See the manor plan from 1796: Geometrische specielle Charte von dem Gute . Friedr. Roehleder. Kattentack den 14 ten December 1796. RA, EA A 854.4.908 ant RA, EAA.3724.4.1512

83 The large property was attended to a by a total of 64 people including a manager hunter, chambermaid, hairdresser, coachmaker, and mailboy: RA, EAA.1864.2.41, 48 When Veldten mortgaged the manor in 1798, its value was recorded at 100,000 silver roubles and 15,000 assignation roubles, and an additional 1,300 assignation roubles for the inventory. RA, EAA.2840.1.336.

84 Field Marshal Burchard Christoph Münnich was the General-Governor of Ingria, Karelia and Finland from 1728 to 1734 . He directed the work for the Ladoga Canal, the construction of the military ports in Kronstadt, Paldiksi and Tallinn, and the fortification in Riga were completed under his direction. The Luunja Manor in Livonia near Tartu was gifted to Ernst's uncle, Oberhofmeister Christian Wilhelm by Empress Elizabet Petrovna. See: Aili Karindi, Elust mõisnike ajal 1503-1919 (Luunja: Karindi, 1999), 17. In 1779 in Luunja a new manorhouse was built. (Pirang, Das Baltische Herrenhaus, 20).

85 From the memoirs of I. Bernulli, the Swiss astronomer and traveller, 1777; quote: Milicia F. Koršunova, 'Juri Feldten', Zodčie Sankt-Peterburga. XVIII veka (Sankt-Peterburg: Lenizdat, 1997), 519.

86 The building was carried out by the local peasants, and therefore, it supposedly cost only 300 roubles. (Information based on the Stenbock family chronicle). 


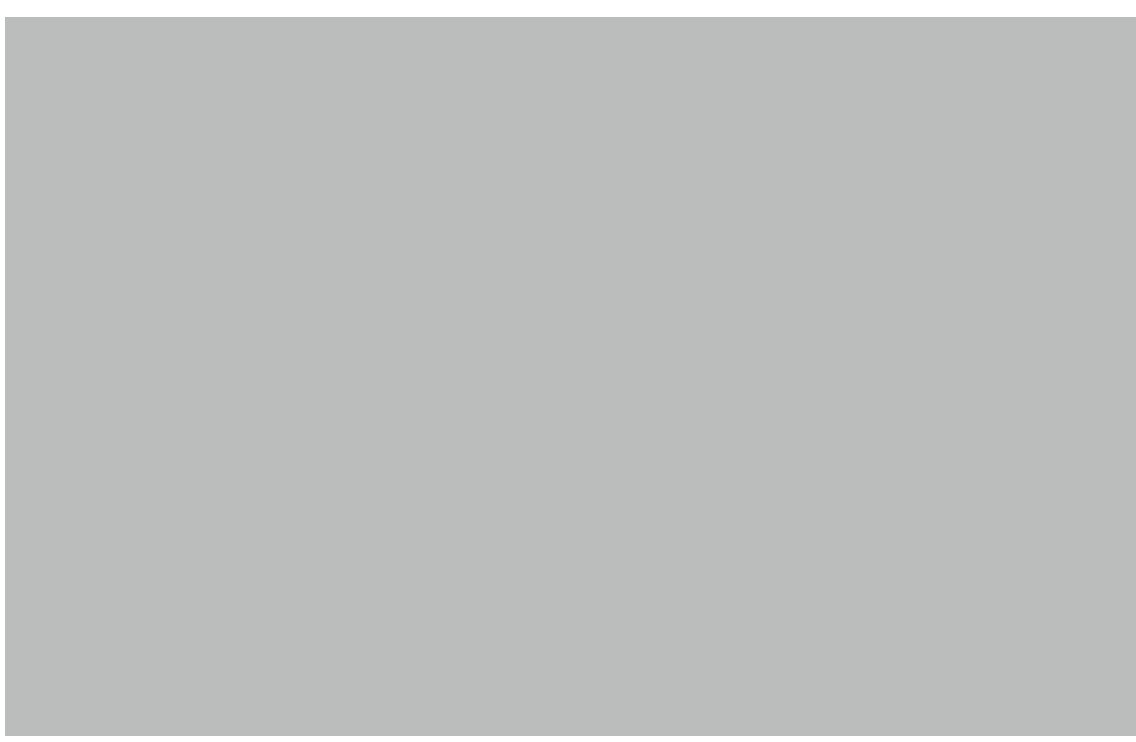

Fig. 23. Aruküla manor house (late 18th - early 19th century). Photo: Juhan Maiste, 2017

indicated by the presence of a music balcony, which was characteristic of the Russian nobility's palaces ${ }^{87}$ In the early 19 th century, the portico became a symbolic element of Baltic manor architecture. In North-Estonia, representative manor houses were built in Tapa (Taps), Valgu (Walck), Haimre (Heimar), Kohila (Koil) and Vinni (Finn), where Countess Euphrosine von Stackelberg founded a Pension house for young noblewomen in 1826.88

One of the largest manor houses in Estonia is Aruküla (Arroküll). Its owner Karl von Toll (born in the small Keskvere (Keskfer) Manor in the western part of Estonia) had made a magnificent carrier at Russian army. Having started at the St Petersburg military cadet school, he participated in a military campaign in Italy, and was appointed to the general staff in 1805. In 1812 Toll was Mihhail Kutuzov's GeneralQuartermaster and participated in the entire campaign all the way to Paris. In 1820, he bought the Aruküla (Arroküll) Manor. The two-

87 In earlier art history writings, this room with a high ceiling has been described as the family's home church. Helmi Üprus, Tallinn aastal 1825 (Tallinn: Kunst, 1965), 359.

88 Founded 16 November 1826. RA, EAA.1442.1.77, 1ff.

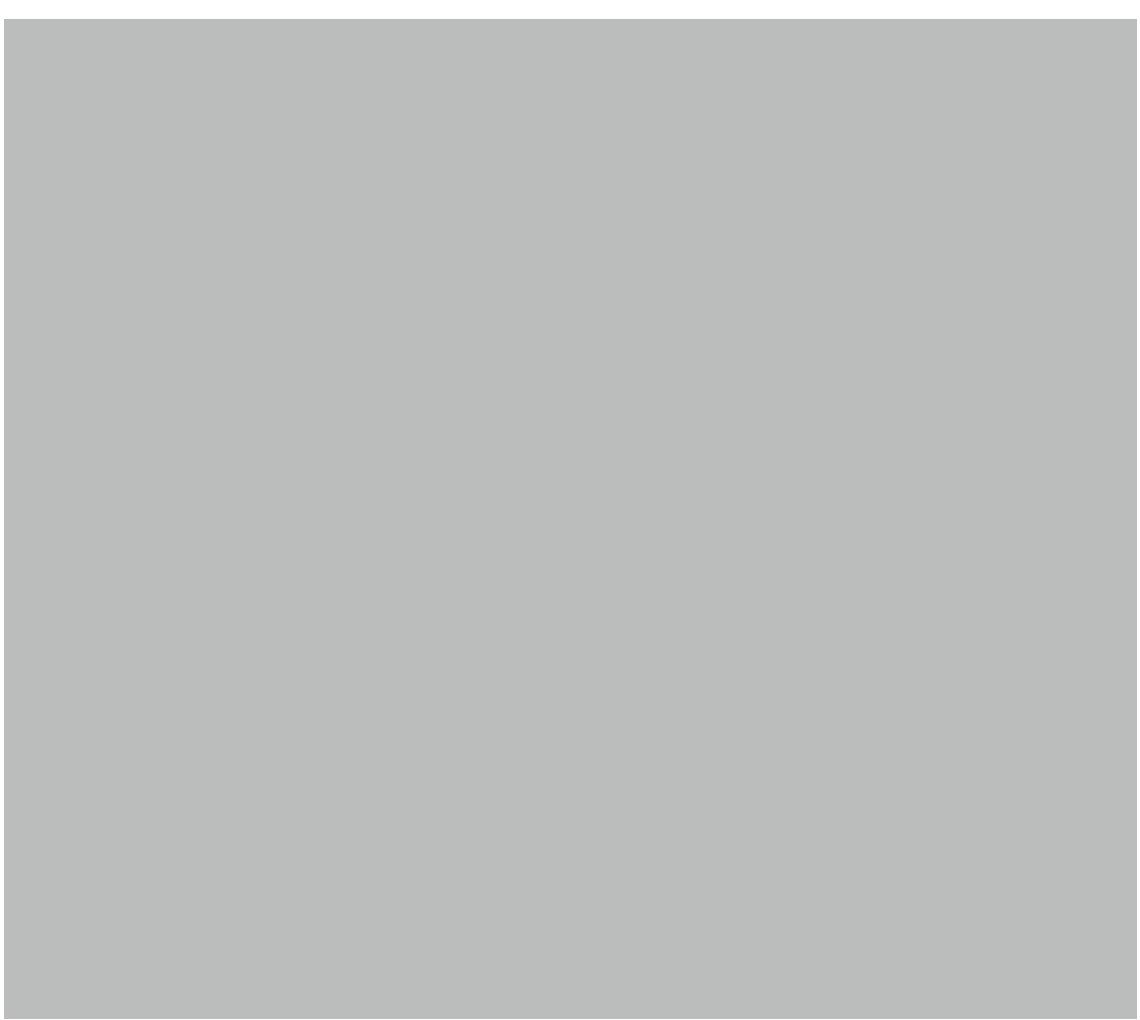

Fig. 24. Riisipere Palace (1818-1821). Facade and first floor plans.

story manor house built by the former owner Frommhold Gotthard von Knorring according to Baltic building traditions, was given a new appearance based on the universal canon of Neoclassicism. Just like Palmse (Palms) Manor, owned by the Pahlen family, the Toll family's Aruküla Manor signified a "harbour of peace" in the idyllic silence of the Baltic provinces, where one could spend a few beautiful summer months and one's earthly remains could be laid to rest in the family chapel. It was as if they were living in two separate times and spaces. The traditions of the past tied the nobility to the coats of arms and class privileges of their forebears and their dreams for the future to high positions in the Russian capital. At Aruküla, the facades of the manor house were embellished with a 
grand columned portico, crossed swords, victory wreaths of laurel garlands, legionnaires' helmets and fasces bundles.

Many of the late 18th century manors were thoroughly rebuilt. In 1810 a portico was added to the Kirna (Kirna) manor house. The patron of the building was Karl Magnus von Osten-Sacken, the Russian ambassador in Denmark. ${ }^{89}$ The ensemble dominant - the manor house - emerges on a small hill. On the walls of the main hall decorated with columns, one could see the portraits of Suvorov, Nelson, Pahlen, Griegh, Orlov and Stroganov hanging beside the portraits of 27 members of the family. The library was next to the hall, and from there one entered the master's study. In the dining room, there was silver tableware with the Osten-Sacken monogram and English table service..$^{90}$

One of the largest neoclassical buildings in Estonia is the Riisipere (Riesenberg) palace built between 1818 and 1821 by Peter von Stackelberg. In the vestibule behind the main entrance, a staircase with treads of Carrara marble leads up to the first floor. On the first floor, unique rows of rooms stretch out on either side, each an example of first-class neoclassical design. A columned hall with an extraordinarily high ceiling is in the building's right wing; and a columned blue room, or dining room, in the left wing. In the centre of the building there is a domed hall (the former painting gallery). The desudeportes with meander and acanthus ornamentation above the doors, high white glazed stoves and massive acanthus rosettes tied with spirals speak a language that attests to a project that has been carefully planned by the architect down to the very last detail; and which, once the building was completed, was supplemented by family portraits and copies of antique sculptures (for example, 'beautiful figures' are mentioned as being in the large hall). ${ }^{91}$ 'Under the direction of Baroness Ungern-Sternberg, the entire place was transformed into a Flora garden /---/. And not only in the park, but also in her own salon, where she had taught the flowers to grow from one column to the next, thereby creating a nest between the

89 The heart of the manor is depicted on one of the maps. RA, EAA.1355.1.5.

90 RA, EAA.17.1.65.

91 Estonian History Museum [Eesti Ajaloomuuseum, EAM]. 96.1.14.

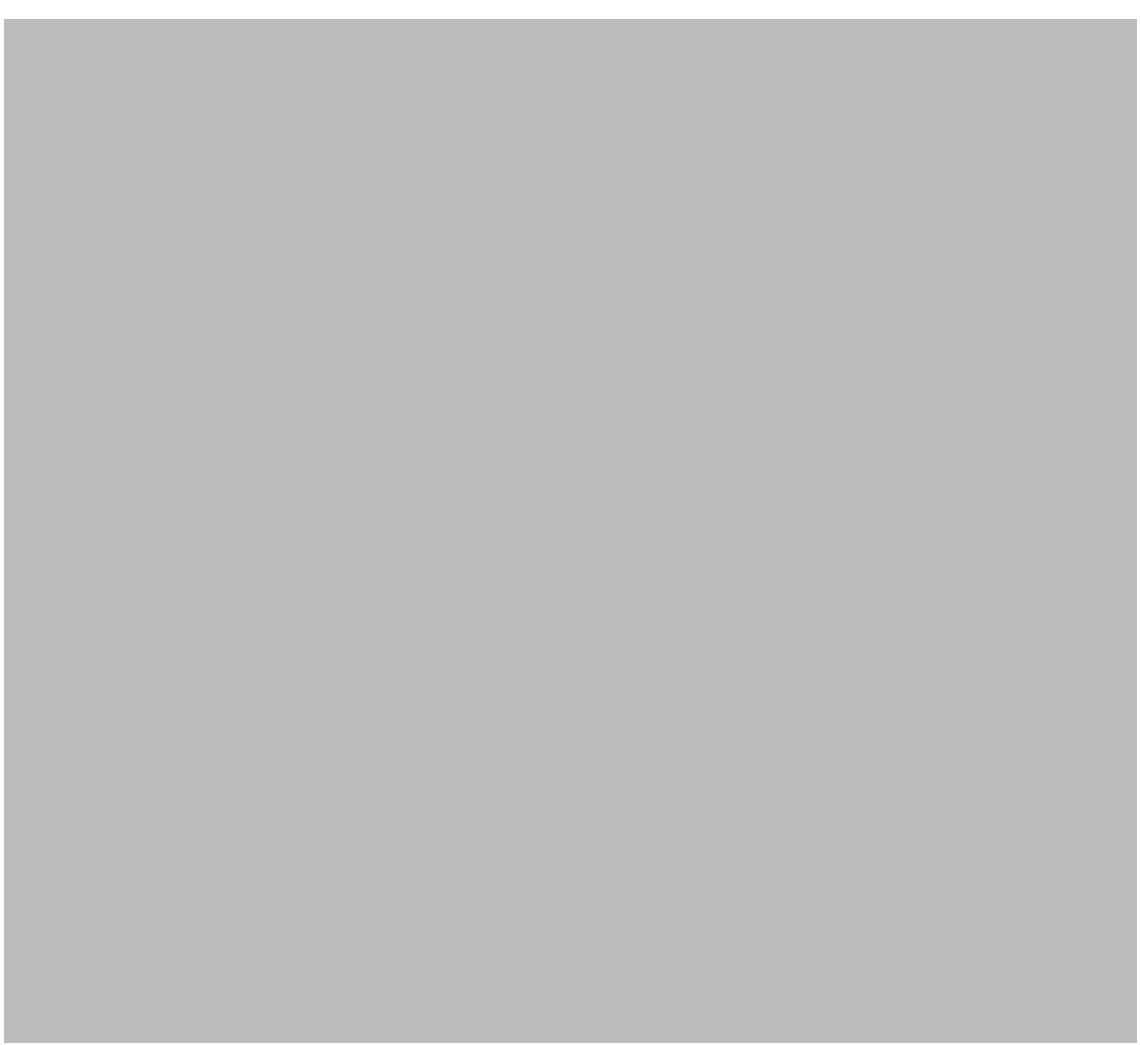

Fig. 25. Raikküla manor house (early 19th century). Facade and first floor plans.

clusters of plants and architectural ornamentation, where small blond Cupids found a hiding place among the perfumes. ${ }^{\prime 2}$

Starting in the early 19th century, large-scale construction work was undertaken at the manors owned by the brothers, Carl Friedrich von Staal (1721-1789) and Friedrich von Staal (1733-1801). The older brother had studied at the University of Kiel, and thereafter joined the army, retiring as a major. From 1765 to 1777, Friedrich von Staal accompanied Prince Peter Ludwig of Holstein on a European tour, and achieved recognition as an art expert, which resulted in him

92 Elizabeth Eastlake Rigby, Letters from the Shores of the Baltic, vol. 2 (London: J. Murray, 1842), 62. 
becoming a member of the esteemed Bologna Academy. Arriving back in Estonia, Staal choose the Järvakandi (Jerwakant) Manor as his home, where large-scale construction took place under his tenure. In 1791, a two-story manor house stood in the middle of the ensemble. Nearly six hectares of dry land was turned into a park, and after preparing the soil, a large number of botanically interesting herbs and medicinal plants were planted in the boggy areas and forest. In total there were over five hundred species, some local and others foreign. A tin sign with the name of the species were installed near each plant. Järvakandi rose amid the surrounding forests and meadows. To achieve a better view, a small hill was created in the middle of the park, where one could see all the surroundings - the recently built paths and lawns, ice cellar and grotto. The grave of the owner Carl Friedrich von Staal (now in ruins) was located a half a kilometre from the manor. The construction of conservatories had been started.93

At that time, Raikküla (Raiküll) and Hõreda (Hördel), which belonged to Friedrich von Staal, were also given a new appearance. And the construction work started by von Staal was continued by his son after his death in 1801: according to the inheritance agreement that came into force in 1808, Raikküla went to Georg Johann von Staal and his brother, Carl Gotthard Friedrich, the Governor of Georgia. ${ }^{94}$ However, the larger-scale building was yet to begin. Thanks to the architect's apt proportional decisions, a place was found in Raikküla for a portico with six Ionic columns as well as for elegant, and also exceptionally abundant, stucco decorations inside the house. Acanthus ornamentation, meander friezes, and white tiled stoves provided a unique combination of the refined tastes of the neoclassical era and the skill to blend the grandiose with the prestigiously finely crafted; to see another plan behind the first; and to propose a solution where the elegance of an oval music salon alternated with the enfilade of formal rooms. In 1847, when the philosopher and the Enlighted mind Alexander von Keyserling

93 August Wilhelm Hupel, 'Ueber die Gartenliebhaberey in Lief- und Ehstland Diplomatische Bemerkungen aus den liefländischen Urkunden', Nordische Miscellaneen, 27-28 (Riga: Johann Friedrich Hartknoch, 1791), 536.

94 In Raikküla, the first large construction project was undertaken in 1804: some of the windows were replaced; new window jambs and double panes were installed, two additional white tiled ovens were purchased and five heating units were repaired. RA EAA.80.1.14, 19
(1815-1891), the future owner of the manor, arrived in Raikküla with his wife, Sinaida and two daughters, as well as the daughter of Count Kankrin, the Russian minister of finance, he was enchanted by the grand, comfortable and extremely friendly manor house. As we can read from the memoirs of his daughter, Helene von Taube, the house had a two-storey-high ballroom, dining hall, blue room, mirrored hall, library, oval hall and her father's study. Many a time, when the weather prevented the owner from taking his traditional walk in the yard, Keyserling would count the 72 steps to his daughter's room (the oval hall), as he walked from one end of the house to the other, and if he traversed that distance ten times, his walk would almost cover an entire verst. The interior design of the building was very stylish for the era, whereas the Keyserlings had brought most of the furniture from their apartment in the Pashkov house in Moscow. ${ }^{95}$

Gideon von Staal, the owner of Hõreda (Hördel) Manor, had served in the military, retired, and then tackled the renovation of the Hõreda Manor which had been left to him as a legacy. As we can see from the inheritance agreement that came into force in 1808 , the legacy included a monetary grant for the completion of the construction of Hõreda, which was 10 hides in size and smaller than his brother's manor. ${ }^{96}$ At the time, the situation at the manor seemed quite hopeless; the construction of the manor house was incomplete, and the remaining buildings, and the governor's house (which is still standing in ruins alongside the road leading to the manor), sauna, stables, barn, two granaries, flax barn and threshing barn were made of wood. ${ }^{97}$ The first thing that the new owner did was start to design the landscape. He had a pond dug in front of the manor house, which surrounded the front yard like a serpent. The entire ensemble was oriented toward the views. A grand aristocratic palace, with a central dome and columned porticos on both wings of the building, rose up against this natural background.

Compared to the palaces of the Russian aristocracy, Hõreda is still small, and more of an extravagant caprice, which astonishes primarily with its artistic level. There is a spacious vestibule in the right wing of the building, where the staircase rises to the first floor,

95 Helene von Taube, Graf Alexander von Keyserling, Bd. I-II (Berlin: G. Reimer, 1902), 278

96 EAM.80.1.76.

$97 \quad$ EAM.70.1.5. 


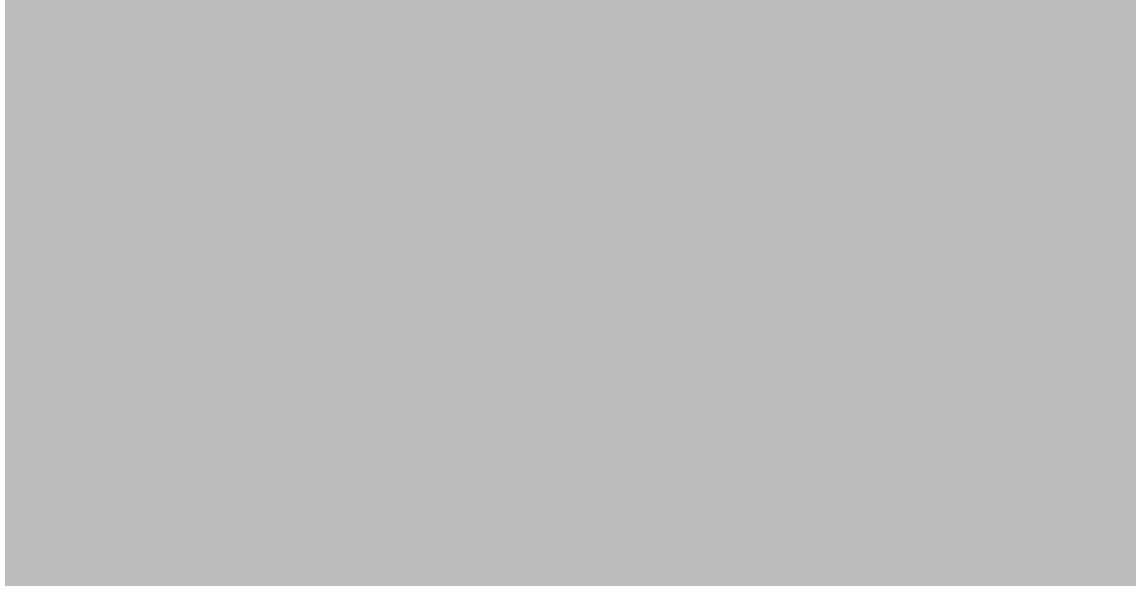

Fig. 26. Hõreda manor house, 1938. Estonian National Museum.

and the long enfilade of formal rooms starts. Walking through the painting gallery, we would arrive in the music salon, where the surfaces of the dome are decorated with paintings that recalled antiquity and were executed in the grisaille technique (fragments of which still survive). Encircling the space is a band depicting a triumphal procession. It is led by Caesar, who riding his chariot has arrived under a triumphal arch, followed by his legions holding their pikes and halberds high. At the end of the triumphal procession, herd animals and slaves are being driven into the Forum Romanum. The square room behind the hall also has a triumphal theme and the subjects of the paintings include Going to War, Battling a Hydra, Arriving Home and The Celebrations Led by the Victoria, the Goddess of Victory. On the lunettes above the doors, we see Venus, Amor and Apollo, who is playing a lyre. The compositions familiar from the Column of Marcus Aurelius and Trajan's Column in Rome are repeated here - the rows of soldiers, which, due to their heroic theme, were copied by artists during the Renaissance. In the case of Hõreda Mantova deserves to be mentioned for another reason: the motto of the paintings, L'entree de l'Emperor Sigismond Mantove refers to the victory achieved by Holy Roman Emperor Sigismund over the papal forces in 1413.
The triumphal celebrations depicted by Andrea Mantegna (14311506) at the Gonzaga Palace in Mantova, which were later brought to Hampton Court gallery by King Charles I, can be seen as a source of inspiration for the Hõreda composition. During the neoclassical period Mantegna's paintings became the favourites of art lovers (including Goethe himself) ${ }^{98}$ and were represented by numerous engravings. Parallels to the work in Hõreda can be found in the work of the decorators and interior designers Carlo and Giovanni Battista Scotti, who came from Mantova, and worked on the St Petersburg home of the Naryshkin family, at the Winter Palace and Peterhof The compositions in the Tauria Palace (e.g. the triumphal parade of Emperor Trajan, the ambassadors of Agamemnon in the tent of Achilles), also include some details that are similar to the Hõreda composition. We should also refer to the drawings made by Scotti in the Stroganov palace in 1818, and to the painting cycle in the Ljublino Manor near Moscow. At Hõreda, Giovanni Battista Scotti worked together with Paridon Jacob Neus, who had previously worked at Vääna (Faehna) Manor as the tutor of Otto Magnus von Stackelberg. ${ }^{99}$

In 1813, the celebration of the wedding of G. v. Staal and Marianne von Salza was held in the recently completed Hõreda manor house. Unfortunately, the costs of the new house had exceeded the revenues. And already in 1819, the owner was forced to mortgage the manor, and the transaction was later formulated into a purchase-sale agreement in 1819. G. v. Staal acquired Pirgu (Pirck) Manor in the vicinity. The domed house with cubic forms seems to have cut right out of a pattern book of English Palladianism, and is reminiscent of Lord Burlington's (Richard Boyle, the 3d Earl of Burlington) famous Chiswick House near London, about which the earl's friends said even in his time: 'the house was too small to live in but too large to hang on the wall like a painting. ${ }^{100}$

98 Detlef Kreikenbom, 'Goethe als Sammler', Goethe und die Kunst, ed. by Sabin Schulze. Ausstellungskatalog (Stuttgart: Hatje, 1994), 68ff.

99 Karl Heinrich Hoheisel, Otto Magnus von Stackelberg als Mensch, Künstler und Gelehrter: eine biographische Skizze (Riga: Livl. Gouvernements-Typographie, 1863).

100 Belov'd by Ev'ry Muse. Richard Boyle, 3rd Earl of Burlington \& 4th Earl of Cork (16941753). Essays to celebrate the tercentenary of the birth of Lord Burlington, ed. by Dana Arnold (London: Georgian Group, 1994), 18 


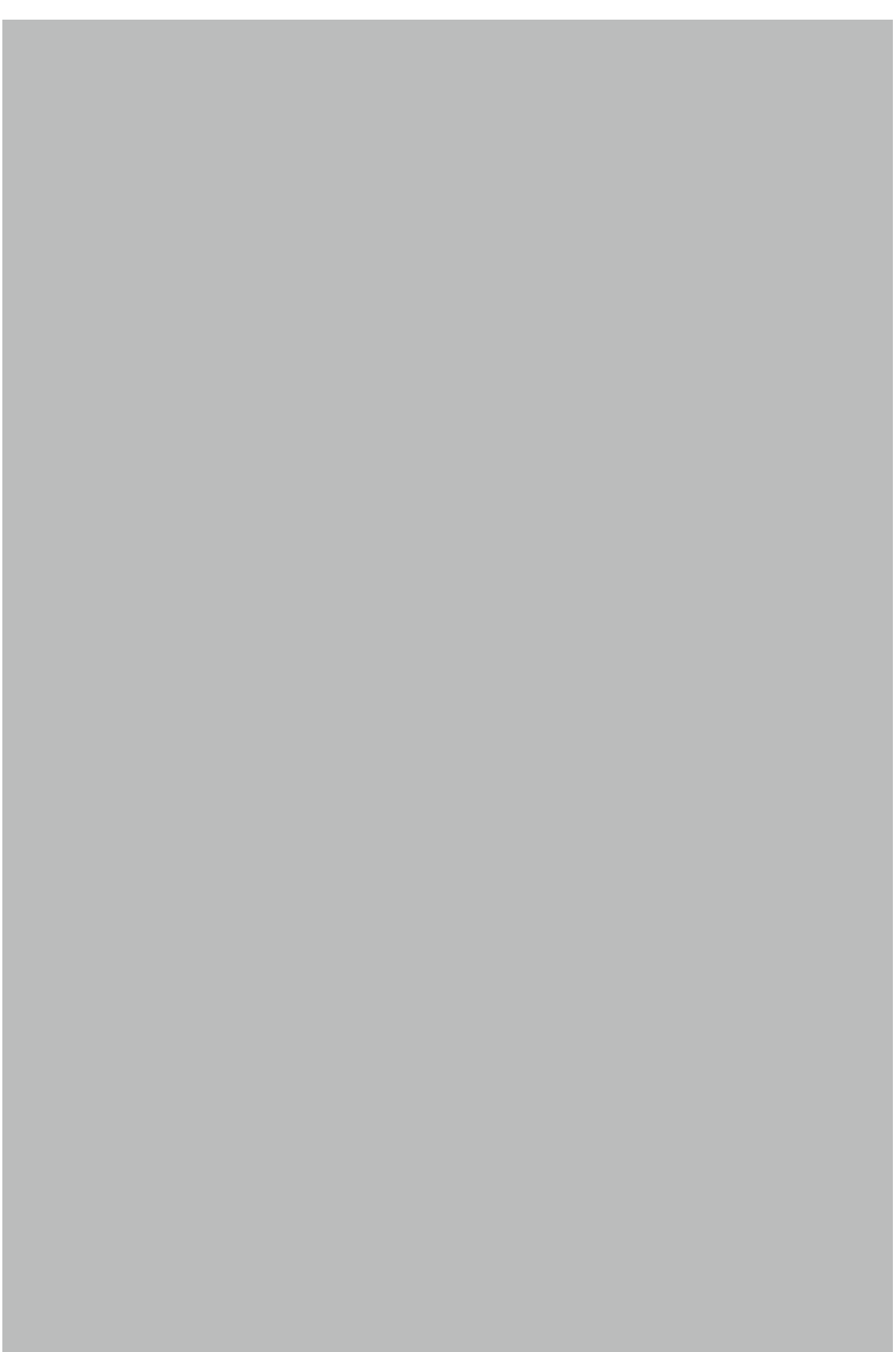

Fig. 27. Saku manor house. Columned hall. Photo: Juhan Maiste, 2016.
The Udriku (Uddrich) manor house was built by an unknown German in 1810 as a copy of the Wörlitz Palace. ${ }^{101}$ The ground and first floors were designed for a ceremonial function: the ceilings on both floors were more than four metres high. Next to the ballroom we find the music salon, with a curved and oval-shaped piano niche that became popular in Baltic manor architecture during the second decade of the 19th century. Baltic manor architecture crossed boundaries, expanded landscapes and provided opportunities for huge stagings. In 1804, Dumoulin, the French park architect, with the agreement of Carl Friedrich von Rehbinder announced that he was hiring German, Russian and Estonian apprentices to work at Saku (Sack) Manor, where they would learn the art of gardening, greenhouse gardening and English-style park design. ${ }^{102}$ In 1820, the manor was inherited by Paul Eduard von Rehbinder. During his tenure, Corinthian-style columns resting on granite staircases were added to the two-storey building. The facades are dominated by the large Venetian style windows. The columned vestibule is designed as an octagonal pavilion. And columns also dominated the large hall. According to Heinz Pirang, the architect of Saku was Carlo Rossi, which is even more possible because of the architect's family ties in Estonia. In 1822, the architect married Sofia Anderson with whom he moved to the Dominican monastery on Vene St in Tallinn after resigning his position St. Petersburg. ${ }^{103}$ The construction of the Saku manor house was underway at the same time as the Yelagin Palace on Vassilyev Island was being built by Rossi. ${ }^{104}$

By the 1820s, Baltic architectural taste had crossed the local borders. The Baltic nobility had found themselves a place in an international circle. In Vigala (Schloss Fickel) an English-style garden had been established already in $1768 .{ }^{105}$ In order to reduce the 'monotony of the landscape', the redesign of Vigala was undertaken again in 1792, at the initiative of Berend Johann von Uexküll. Many of his ideas were inherited from his close relative Jacob Johann von Sievers, who had

101 Based on historical tradition, the Udriku architect came from Germany: Linda Vilmre, Collected in the summer of 1931. EKLA, f. 199, m. 55, p. 62.

102 Revalsche Wöchentliche Nachrichten, 8 (1804)

103 Marianna Z. Taranovskaja, Karl Rossi (Leningrad: Lenizdat, 1978), 169ff.

104 Nikolai Veinert, Rossi (Mocow-Leningrad: Iskusstvo, 1939), 24

105 In 1768, indicated on the manor map under the name 'Der Englischer Garte'. Margit Tohver, Vana-Vigala mõisapark. Dissertation (Tartu: University of Tartu, 1997). 
served in the Russian Embassy in England. The previous owner of several manors in the Latvian part of Livonia and in Russia, who had been the governor of Tver, Novgorod and Pskov and a senator as well, von Uexküll set out to update his father's home Baunu muiza (Bauenhof). The main building had been inspired by English country homes and rows of foreign trees were planted, with the seeds being sent by mail from Germany. ${ }^{106}$ As Berend von Uexküll writes in his memoirs, Vigala reminded him of the English gardens of Windsor and Blenheim. 'The park was designed in the English style, except for one section where the fir trees were planted in rows, which was called the "German forest". Three paths crossed the park, whereas two were so-called "English paths" or "grass paths".'107

The manor comprised a microcosm, where the idea of a Baltic 'pantheon based on natural philosophy'108 achieved its apogee by establishing the basis for the so-called Baltic still life (Baltische Stillleben ${ }^{109}$ ). Like Persian rugs in different colour combinations that covered the floors in the salons of the manor house, it was difficult to differentiate the impulses and patterns at play here. One's homeland was Europe, and Europe was in turn Russia, where according to Alexander von Keyserling: 'The human instinct for nationality was more like a religion that was battling with the higher ideals related to the general humanity. ... If anyone yearns to see a land where people live without bureaucracy, without learned jurists and chancellery secretaries, head our way.'110

In one short moment, the dream of an ideal state became a reality. When Alexander von Benckendorff acquired Keila Joa (Fall) Manor near Tallinn in 1827, he gave Hans (Andrei Ivanovich in Russian) Stackenscheneider, a young and then relatively unknown architect,

106 Friedrich Eberhard Rambach, Jacob Johann Graf Sievers (Dorpat: M. G. Grenzius, 1809), 51-52.

107 Berend von Uexküll, ‘Erinnerungen an Schloss Fieckel und die Nachkriegszeit in Berlin und München', Zwischen Reval und St. Petersburg. Erinnerungen von Estländern aus zwei 108 Jaan Undusk 'Das baltische Pantheon in der Naturphilosphie. Baer, Uexküll, Ostwald und das Problem der Zeit', Umweltsphilosophie und Landschaftsdenken im baltischen Kulturraum, ed by Liina Lat Underi ja Tugalse Kirjanduskeskus, 2011), 112ff.

109 Julius Eckardt, 'Livländische Stillleben', Die baltischen Provinzen Russlands.Politische und kulturgeschichtliche Aufsätze (Leipzig: Duncker \& Humboldt, 1868), 420ff.

110 Alexander Eggers, Baltische Briefe aus zwei Jahrhubnderten (Berlin: Deutsche Bibliothek; Leipzig: Spamer, [192-?]), 165-166.

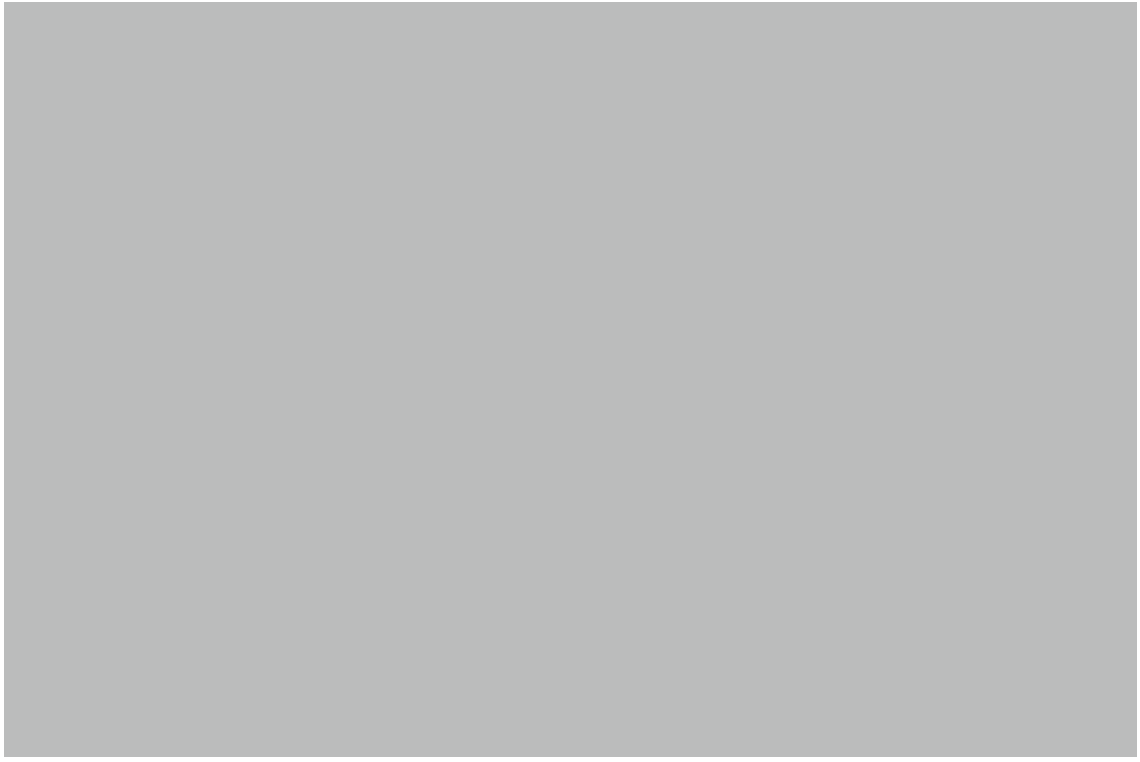

Fig. 28. Keila-Joa Castle (1830s). Architect Andrei Stackenschnaider. Photo: Juhan Maiste, 2016 (after restoration).

the assignment of designing the palace in the Gothic Revival style, which had become popular in Russia already during the reign of Catherine the Great. ${ }^{111}$ The new building was supposed to be reminiscent of the cottage designed for Alexandra Feodorovna the wife of Nicholas I, which had been constructed in Peterhof based on the plans of Scottish architect Adam Menelaws. When Elizabeth Rigby, an English lady and the wife of the director of the National Gallery in London visited Estonia in the 1840s, she was amazed by the wonders she saw at many of the manors: 'Who would imagine that this good, honest fertile Estonia - this stronghold of old fashion decorum - this formal, straight - walked nursery of clipped thyme and rosemary - that this precise, decorus province is a reared pavilion of luxury - a private theatre of fashion - a salon of modern manner, owning no bounds but an invisible ring - fence

111 Sergei Kuznetsov, 'Pointed arch on a Doric Column. The Graeco - Gothic discourse of Catherine the Great and architecural - spacial representations of power in the Russian Empire (1770-1830)', Enlightenment Gothic, ed. by Vasily Bazhenov (Moscow: In Artibus, 
of refinement, where all taste, expense, and indulgence - all nature and all arts are combined... It is not Estonia - that is sure; it is not Russia - here is no disorder; nor France - though the echoes answer in French number; nor England - though as like as any. What is it, then? Where are You? In beautiful, delicious, unique Fall - the garden of nature. ... the potpourri of all nations - the quintessence of all tastes; where the courtier, the artist, the man of sense, or the man of nonsense, may all be happy in their own way.'112

\section{THE DICTATES OF THE METROPOLIS AND THE ‘OBEDIENCE' OF THE PROVINCE}

At a time that Europe was being ravaged by revolutions and the Napoleonic Wars, Old Livonia, as the western provinces of Russia were still called affectionately at the time, found themselves in a peculiar situation. The spirit of Goethe and Schiller, which had spread in the Baltic countries along with the teaching of Kant, Voltaire and Rousseau, provided an impetus for the popularisation of the ideas of Enlightenment among the new intelligentsia and the old nobility, by, on the one hand, arousing interest in the history of the land and the monuments and traditions that preserved the past, and on the other hand, by the adoption of the international cultural experience and assimilation, which in the ultimately makes it almost impossible to differentiate individual impulses - regardless of whether they came from the French, English German or Russian cultural context. The basic nature of the Baltic cultural genius was cosmopolitan, and its orientation extended far beyond the borders of its homeland, and in the early 19th century including all the farthest lands, including the activities of Otto Magnus von Stackelberg as an archaeologist and artist in Greece, Otto Friedrich von Richter's expeditions in Egypt and the Middle East, and Adam Johann von Krusenstern's circumnavigations.

At the same time, the culture of the Enlightenment found itself imprisoned by two social and political realities in its own ancestral home - between a social order that had outlived its time and an abundant bureaucracy. If initially, the German language, which was recognised as the language of the upper classes in the provinces,

112 Rigby, Letters from the Shores of the Baltic, vol. 2, 142-145, 159. was difficult to replace with Russian, the greater became the wish to change the visual standards. Catherine the Great has already taken steps to establish standard building facades throughout the country. The country's best architects were involved in drawing up the sample facades (obroztsovye fasady). ${ }^{113}$ In 1803, St Petersburg architect Andrian Zahharov had completed a set of sample drawings for the construction of state institutions, schoolhouses, prisons and other public buildings. ${ }^{114}$ Between 1809 and 1812, the standard facades that were established (tipovye fasady) opened the way to modernising the entire empire. ${ }^{115}$ The full set of plans for the standard facades, which was ordered by the Tallinn town council, did not arrive until 1811. In 1821, Sammlung der Allerhöchst bestätigten Aufrisse zu Fassaden von Privathäusern sowohl als auch von Zäunen und Pforten in der Städten with its 287 drawings came on sale in the bookstores; unbound it cost 72 roubles, 77 roubles in a good binding, and 95 in a red Morocco leather binding. ${ }^{116}$

As a matter of fact the classic models, which were once perhaps dreamed about in the imperial court, became their opposite in practice. A so-called "double standard" applied: on the one hand the philanthropic ideas of Alexander I to make Russia more European; and on the other hand, the need to establish control over the provinces. The models for the standard facades were the awardwinning works from the French Royal Academy of Architecture, which along with social determination emphasised revolutionary utopia and an imaginary scale in urban construction. And in some paradoxical way, these found a new home for themselves in St Petersburg and Moscow, in an empire where the spark of 'liberty, equality and fraternity' was extinguished after a short while. ${ }^{117}$

113 In 1803, St Petersburg architect Andrian Zahharov completed a set of sample drawings for the construction of state institutions, schoolhouses, prisons and othe public buildings.

114 Ožegov, Tipovoe i povtornoe stroitel'stvo v Rossii v XVIII - XIX vekach, 100ff.

115 A total of five volumes, which include the drawings of 224 residential and auxiliary buildings and 60 drawings of fences and gates. The Scotsman William Hastie was the editor of the first collection of standard facades. Sobraniye fasadov Vysochayshe aprobirovannykh dlya chastnykh stroyeniy v gorodakh Rossiyskoy imperii, I-V (St Petersburg, 1809-1812).

116 Revalsche Wöchentliche Nachrichten, 26 September 1821.

117 Juhan Maiste, 'Revolutionary Architecture in the East. - The Problem of Classical Ideal in the Art and Architecture of the Countries around the Baltic Sea', Estonian Academ of Arts. Proceedings, 13 (Tallinn: Eesti Kunstiakadeemia, 2013), 216. 
In the old Hanseatic town the standard facades created all sorts of the resistance. As can be seen from the reports submitted to the provincial government, in 1810 Carl Ludwig Engel, the town architect who has arrived from Berlin ${ }^{118}$, notified the provincial government that only four buildings had been built in Tallinn based on the facade models, and three had been built in 1811. At the same time, the number in St Petersburg was 346, in Schlüsselburg 30, in Luuga 27, etc. ${ }^{119}$ In 1814 and 1815, only three houses were built in the old Hanseatic town based on the approved model; in 1812, 1816 and 1817 none were built in Reval. ${ }^{120}$ Even in 1819, Lieutenant General Gregor von Berg, the commander of Tallinn, notified the head of the provincial government's building department that many houses had been built in Tallinn during the summer, but without getting permission from the engineering brigade or complying with the façade requirements. This opposition, which was not easy to overcome, continued until the end of Engel's time in Tallinn. In 1827, when he was already working in Finland, Engel wrote the following to Carl Herrlich, a friend from youth: 'Freilich hat der talentvolle geniale Architect, der die Baukunst ganz beherrscht und ein denselben Formen kleiden kann, Gehemnisse, vor einen Stimpen und talent losen Baumeister vor aus, die diesem ewig als Räthsel erscheinen müssen, da er nie erlernen kann, weil dies nicht su erlernen, sondern eine Gabe des Himmels, die jedes Dichter ist. ${ }^{\prime 21}$

Tallinn is not a city where poetry is of prime importance. Throughout time, other rules have applied here. Architectural rhetoric has almost also been in the service of the state and power. In 1820, the engineering department of the provincial government was given the assignment of conducting a survey of Tallinn's streets and buildings, based on which, a set of drawing was produced after a few years. Eight pages of Old Town facades and 21 suburban facades from this set have survived until the present day. ${ }^{122}$ One can assume that the long-term goal was to draw up plans for making a model of the town (as had been done in 1683). In Italy, the custom of making town models

118 Carl Ludwig Engel was the Tallinn town architect from 1809 to 1813.

119 RA, EAA.30.1.995, 2

120 RA, EAA.29.1.236.

121 Engel, Kirjeet, 432.

122 RGVIA, 3-2, 537-544. Published: Üprus, Tallinn aastal 1825.

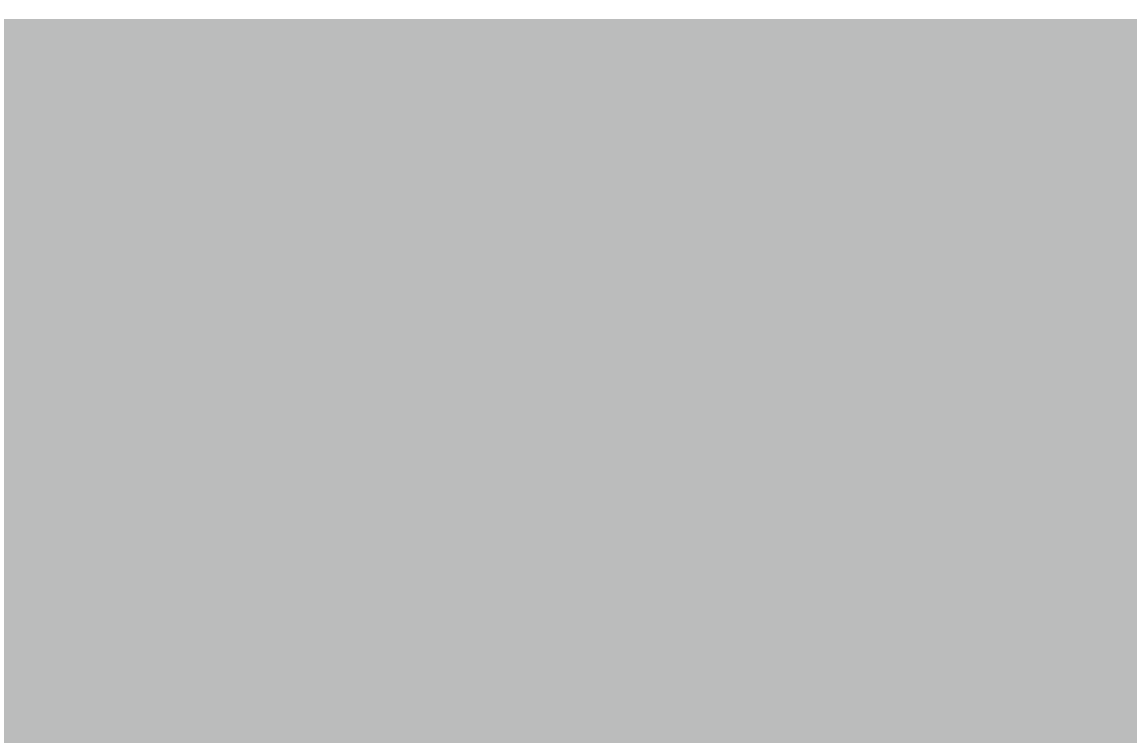

Fig. 29. Toompea. Drawing by the English lady, Elizabeth Eastlake (Rigby). Elizabeth Eastlake, Letters from the Shores of the Baltic, vol. 1 (London: John Murray, 1842).

dates back to the Renaissance. A collection of architectural models (Modelsammlung) existed in the Tartu cabinet of architecture, which had been started by Johann Wilhelm Krause. ${ }^{123}$ A model of Riga was also commissioned in the early 19th century. The state continued to exert pressure for the continuation of construction activities. In 1825, Marquis Filippo Paulucci, the Governor-General of the Baltic provinces, enacted building regulations for Tallinn and its suburbs, para. 95 of which precisely describes the owners' responsibilities, the sizes of the lots, and the facades. It was prohibited to build houses with their end walls facing the street. The roofs of all the houses in town had to be covered with roofing tiles or tin. The number of floors depended on whether the house was located on main or side street. The colour of the buildings was to conform to the era; and this also applied to the facades and details (window openings, doors, etc.). To comply with fire safety regulations, the houses had to be at least 


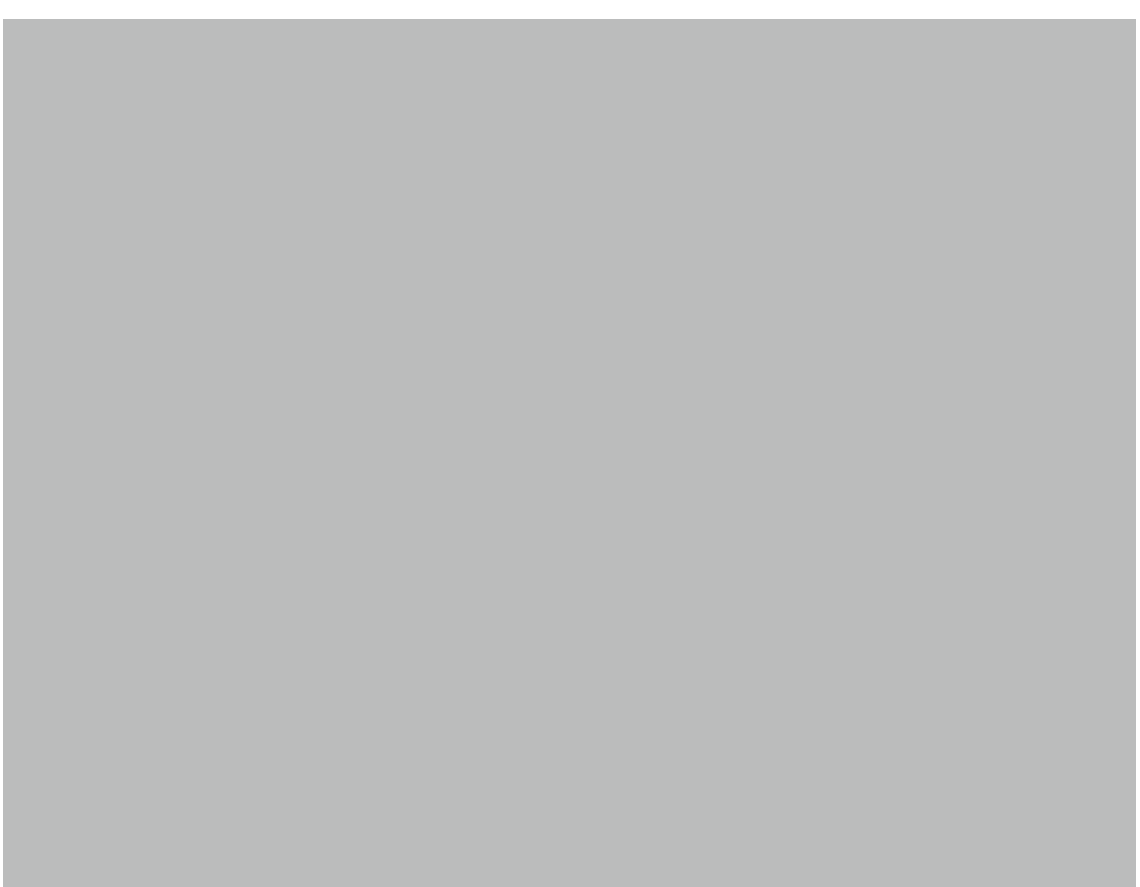

Fig. 30. Plans for the city palace at Vene 15/Pühavaimu 8, floor plans. Drawing by Johann Daniel Bantelmann, 1820. Estonian Historical Archives.

10 fathoms (i.e. more than 21 metres) apart, and the fences were to be 9 feet tall $(2.8 \mathrm{~m}) .^{124}$

In time, the standard facades were accepted in the city. But, in most cases, they were viewed as being more bureaucratic than essential for the professional architects. In practice, the existing conditions were a determining factor, i.e. construction had to be done on narrow lots within the medieval walls. Based on the lack of space, in the facade drawings as well, the facade line on Tallinn's streets is densely filled with medieval houses from the Hanseatic era. Having been built between the 15th and 16th centuries, the facades reached toward the heights, thereby overshadowing the rows of auxiliary building hidden in the depths of the lots. The structure of Toompea, with its residences and courtyards of the nobility, differed from the Old Town.

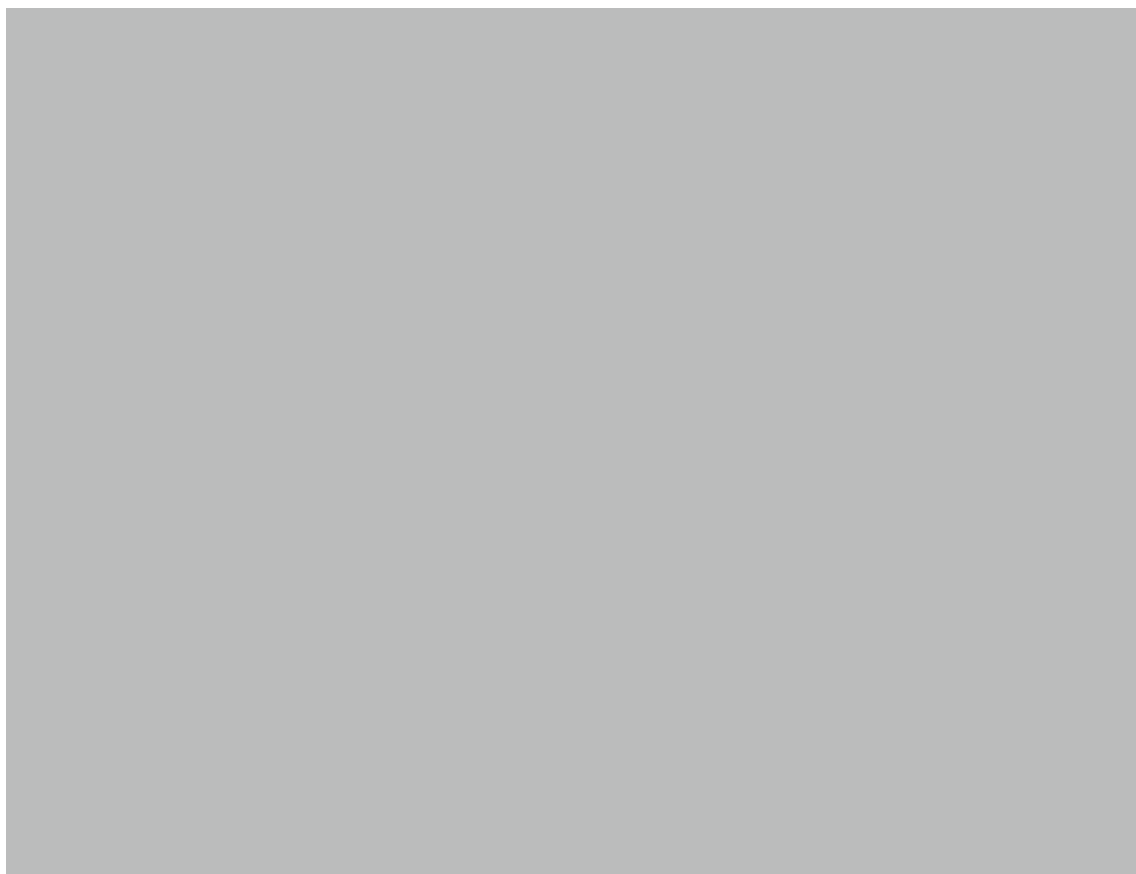

Fig. 31. Constantin von Ungern Sternberg's city palace, Lai St 5. Drawings of the facade, ground and first floors, 1831. Russian State Historical Archives.

There was more space and an opportunity to solve architectural issues based on the styles of the neo-classicist era, as required of the city palace (hotel) that had taken root in France, or the osobnjak or mansion, which was adapted as the urban residence for the Russian nobility. In the 19th century, the upper town and lower town were comprised of two dramatically different living environments.

Most of the standard facades in both cases remained formal. The number that referred to the facade collection at the bottom of the drawing indicated state control and approval. Architectural quality was achieved more by the individual solutions that the highest ranks of the citizenry could afford. The palaces of the nobility that were built on the high limestone plateau hung above the town. 'The picturesque remains of massive walls and towers which continue the line of elevation to a giddy height, and rival the rocks as much in solidity as in time - worn blue, engross a considerable portion of 
the outer ring, the remaining segment being possessed by some of the principal mansions, many of them of great magnificence, which start perpendicularly from the rock, in some instances without an inch of space beyond, and offer views soaring wide over land, sea and sky, and windows whence one shudders to look down.'125

As time went on, the more buildings with imposing neoclassical facades found a place in the lower town. One of the larger houses rose on three medieval lots at the intersection of Niguliste and Rataskaevu Sts. The lots belonged to Hans Heinrich Falck and the building was designed by Johann Schelbach, the provincial architect. ${ }^{126}$ On Lai St, one of the main streets in Old Town, the client was Konstantin von Ungern Sternberg, for whom Engel designed an imposing city palace on the corner of Pühavaimu St and Vene St (Pühavaimu St 8/Vene St 15). The years after the Great Northern War play a part in the story of the building's construction. Having suffered extensive damage during the war, it stood in ruins for a long time. And in 1797, two adjacent lots were acquired by Lieutenant General Gustav Ernst von Strandmann (1742-1803). As the result of his daughter's marriage, the property was transferred to Constantin von Ungern Sternberg, the owner of the Hiiu-Suuremõisa Manor, who had acquired considerable wealth as the supplier of vodka and grain during the Franco-Russian War. As a result, the man had acquired a dozen manors including Hüüru, Harku, etc. in North-Estonia. In 1829, Constantin, along with his brother Heinrich established the broadcloth factory in Kärdla (Kerdel). His palace at Lai St 5, which was designed by architect Gottfried Henning from Mitau and Carl Ludwig Engel and stood next to Tallinn's first theatre, testifies to the new approaches that became rooted in the 1820s. By rebuilding the old Hanseatic buildings, the local architectural heritage was combined with the architectural idiom of neoclassicism. This is indicated by the balcony built above the arched gate that dates back to the Hanseatic era, as well as the so-called Venetian (Serlio) windows ${ }^{127}$ that had become predominate in the capital, St Petersburg.

Regardless of the transfer of state power, Tallinn remained a German town even under Russian rule. As Aleksandr Bestužev, the

125 Elizabeth Eastlake Rigby, Letters from the Shores of the Baltic, vol. I (London: J. Murray, 1842), 257-258.

126 RA, EAA.33.3.115, 68

127 RGVA, 349, Reval, 537

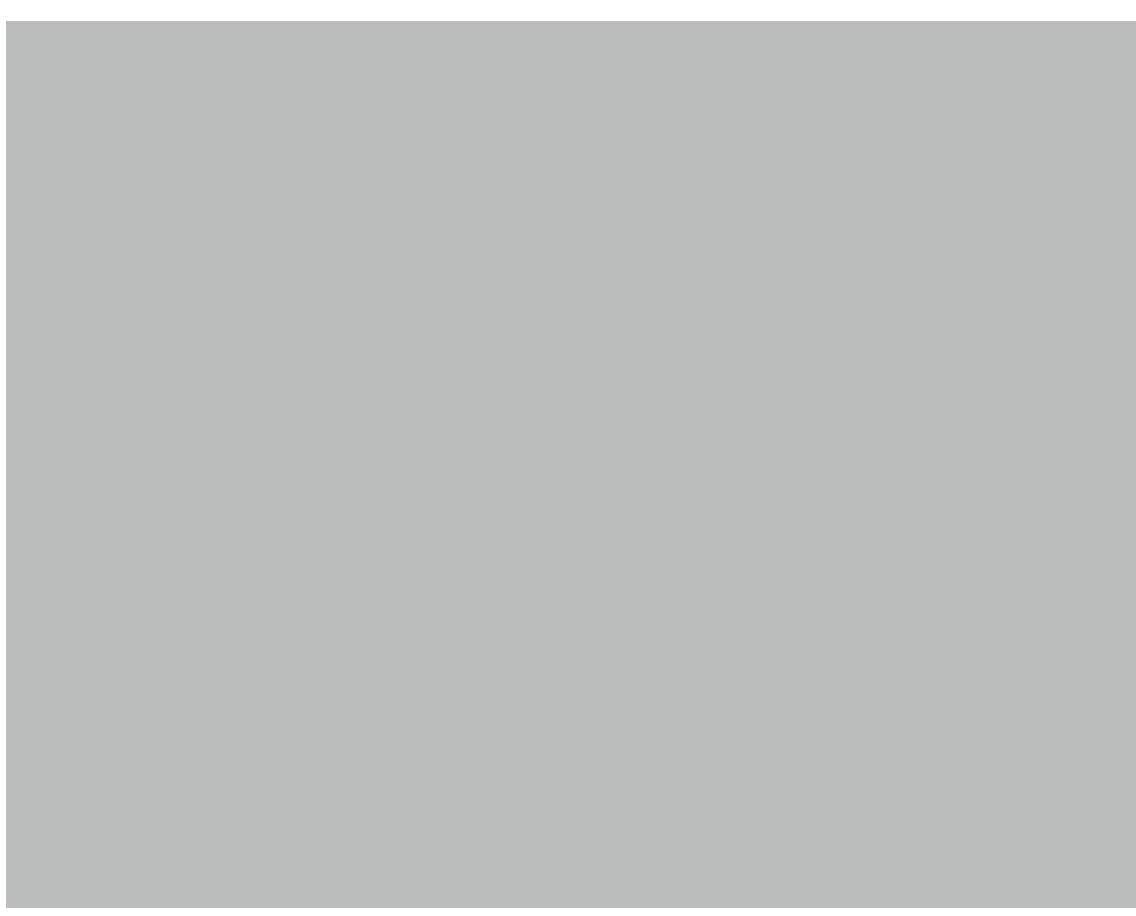

Fig. 32. Alexander Nevsky Cathedral in Tallinn. Photo: Ivar Leidus, 2013.

Russian writer and Decembrist, wrote in 1820, quite a bit of Russian could also be heard in the town, and almost everyone spoke French - but the preferred language was still German. 'The streets meander through each other, and intersect; one street imperceptibly becomes another, without any of them following each other's or their own definite paths. /---/ The buildings in the town are quite tall, pyramidshaped, decorated with red "glazed" brick roofs and windows and doors that are placed as if on a chessboard. /---/ The entire town resembles a military camp, and as a precaution, the merchants have reinforced their entryways. The living rooms are located in the rear, the storehouses and office in the front, which is suitable for protecting one's life and merchandise. /---/ The cleanliness in the houses is noteworthy.' ${ }^{128}$ 


\section{EPILOGUE}

In 1887 , the Orthodox Russians made the following appeal to the Orthodox believers throughout Russia: 'Our brothers in faith, who live on the shores of the Baltic Sea, we in the city of Tallinn send you greetings and ask for your brotherly assistance. Help us to carry out a holy initiative - to build a cathedral in the city of Revel, which is dedicated to Prince Alexander Nevsky.'129 A collection of funds was started that involved the entire empire. Although there were no official documents that clearly outlined the main features of the Russification policy, the programme supported by Alexander III provided the impetus for ethno-social movements, which on the one hand, led to the retreat of the German language and culture, and on the other, to an emphasis on the privileges of the Slavic peoples and their consolidation from the Balkans to the Baltics. Those charged with carrying out the Russification political programme were Sergei Sakhovskoi in Estonia and Lieutenant General Mikhail Zinovyev in Livonia. The provinces that had been relatively autonomous were now supposed to become 'organic components' of Russia. ${ }^{130}$

The transition to Russian Orthodoxy began during the time of Tsar Alexander II. Orthodox believers in the Baltic States enjoyed the most favourable treatment during the second half of the 1860s and the first half of the 1870s, when a programme for the construction of churches supported by what was called the 'Russian deal' (russkoje delo) and the Russian Interior Ministry (tserkvno - stroitelnaja operatsija) led to the construction of tens of new Orthodox churches. ${ }^{131}$ In addition to Russian architects, architects and engineers from Riga were also involved in the design of churches: among them Karl Heinrich Scheel (Latvian: Shels), Alexander Johann Friedrich Baumann (Baumanis), Robert August Pflug, Julius August Hagen and others. The stylistics used in church building in most cases differed from the 'Russian

129 Karl Tizik, Revelskii Aleksandro - Nevski sobor na Võ̌sorode (Revel: Rvelskije izvestia 1900), 13.

130 Toomas Karjahärm, Venesatamisaeg, Eesti ajalugu V, Pärisorjuse kaotamisest Vabadussõjani, ed. by Toomas Karjahärm, Tiit Rosenberg (Tartu: Ilmamaa, 2010), 271.

131 Aleksander Bertash, 'Tserkovno - stroitelnaja operatsija: provintsialnoje tserkovnoje stroitelstvo kontsa 1860-1870 godah na territori Latvi i Estoni', Orthodoxy in the Baltic Religious Life, Policy and Education 1840s-1945, ed. by Irina Paert (Tartu: Tartu University Press, 2018), 43. style' as well as that of overseas examples promoted by K. A. Toni, balancing the style of 'Russian romance' and 'Byzantian romance' in the Riga school. ${ }^{132}$

The situation changed after the assassination of Alexander II (Alexander the Liberator) and Alexander III rose to the throne in 1881. Russification then acquired a more acute political significance. Rhetoric was used to communicate the desire of Russian outlying regions to join the Orthodox Church and to harmonize nationalreligious feelings throughout the Russian Empire. ${ }^{133}$ The method for conducting the Russian messianic mission became the widespread promotion of the Orthodox religion, which culminated in a massive religious conversion movement in the early 1880s. The economic advantages provided by the Russian Orthodox Church resulted in a noteworthy number of rural and urban residents coming 'under the auspices' of the Russian church, which was accompanied by a largescale building campaign. ${ }^{134}$ But if we look deeper into the issue, we can see it was actually a political solution. In Tallinn, the Alexander Nevsky Cathedral was built in the most visible location in the city, where only recently the Estonian Knighthood had planned to erect a bronze statue of Martin Luther (upon its completion it was installed in front of the parsonage at Keila (Kegel), and destroyed during the Soviet era). To create room for the cathedral, several houses of the nobility surrounding the site were demolished.

The plans for the church were commissioned from academician M. T. Preobrazhensky, who was a recognised expert on Old Russian architecture. In 1895, the cornerstone was installed with great ceremony. Five hundred soldiers from the White Sea hauled a bell

132 Aleksander Bertash, 'Tserkovno - stroitelnaja operatsija: provintsialnoje tserkovnoje stroitelstvo kontsa 1860-1870 godah na territori Latvi i Estoni', Orthodoxy in the Baltic: Religious Life, Policy and Education 1840s-1945, ed. by Irina Paert (Tartu: Tartu University Press, 2018), 92.

133 Aleksandr Polunov, 'Imperija, pravoslavije i problema reform v Pribaltike: $\mathrm{k}$ ( University Press, 2018), 207-208.

134 According to the 1887 Russian census, in South-Estonia, the rural Orthodox population was $18.7 \%$ and in North-Estonia 14\% of the population. $28.6 \%$ of the Orthodox believers lived in the towns and were mostly Russians. The largest congregations were in Narva $(44.6 \%)$ and Kuressaare (31 \%), followed by Parnu (21.9\%), Valga (22 \%), Paldisk $(11.8 \%)$ and Tartu (11.7\%). Jaanus Plaat, Õigeusu kirikud, kloostrid ja kabelid Eestis. Orhodo Churches, Convents and Chapels in Estonia (Tallinn: Eesti Kunstiakadeemia, 2011), 56. 
weighing 979 poods ${ }^{135}$ up to Toompea Hill, which, along with ten lighter weight bells cast in the Orlov factory in St Petersburg, ${ }^{136}$ now helped to relieve the concern of the Tallinn Orthodox believers that the sounds exalting the true religion were seldom heard in the city. ${ }^{137}$

The year 1917 saw not only the collapse of the political system, but also a reassessment of values. Rolf von Ungern Sternberg, one of the contemporaries of the day, who had spent his youth in the family house at no. 7 Lossi plats (Church Square) opposite the Russian cathedral, wrote the following about the situation to his friend and philosopher Alexander Keyserling: 'All of Europe is splintering and seems to be collapsing, which is a sign of destruction for us and our roots. ${ }^{\prime 138}$ In the 1920s, a heated discussion developed regarding the reconstruction of Alexander Nevsky Cathedral into an Estonian pantheon. ${ }^{139}$ And Estonian architect Karl Burman prepared the necessary plans. In 1936, plans were completed by Alar Kotli for the total reconstruction of Toompea Hill, which, along with other features, called for the demolition of the cathedral and the design of a grand square in front of the parliament building to replace it. ${ }^{140}$

The more variegated the dress, the richer the history. Looking back, the impact of Russian architecture in Estonia can generally be divided into three periods: a) from 1710 to 1800 ; b) between 1800 and 1840; and) from 1840 to 1917. This has also left its imprint on the land, and we are still waiting for a summation and examination of all this to be made. The summary of this article is an acknowledgement of the special place occupied by the Baltic countries, and the singularity of its aesthetic thought. All of this requires an effort that involves reading not only one, but all the hefty tomes on European art and history. This is the only way that the collage can be discerned, the single sections of which are fragments of a mosaic sparkling in the light of the great art history of the large nations of the world, and whereby the field of vision of the art historian's laboratory, with all

1351 pood $=16.38$ kilograms.

136 Ants Hein, 'Tallinna Aleksander Nevski katedraal. Arhitektuurist ja arhitektuurivälisest', Ehituskunst, 2/3 (1986), 102-103.

137 Tizik, Revelskii Aleksandro - Nevski sobor na Võ̌sorode, 3.

138 Henning von Wistinghausen, Der Estländer Rolf Baron Ungern-Sternberg als russische Diplomat 1905-1917, 36 Jg., H. 1 (Marburg: [s.n.], 1987), 481.

139 Mart Kalm, 'Paraadplats Toompeale', Reede, 1 September 1989.

140 Ibidem. its uniformity and contradictions, becomes visible. Both a telescope and a microscope are needed to achieve this, along with gauges that can register the surface ripples as well as the deep undulations.

Juhan Maiste: The Concept of Russian Architecture in the Baltic Provinces between the Great Northern War and the Cosmopolitanism of the 19th CENTURY

Keywords: cultural geography; Russian architecture; Baltic Provinces; Italian architects; Manor houses; CHURCH ARCHITECTURE

\section{SUMMARY}

The goal of this article is to examine the role of the new Russian ruling power as it related to cultural policy in the Baltic provinces between the Great Northern War (1700-1721) and the Russian Revolution (1917) in order to engender a discussion about the Russian influence in Estonia's architectural history - its content and meaning - based on primary sources in the archives of Estonia, St Petersburg and Moscow. The historiography of this topic dates back nearly a century; as a neighbouring country and an important centre of political power and culture, the influence of St Petersburg as the main Russian metropolis has been always been taken into consideration and studied in the history of Estonian art history. The articles by Sergey Androsov and Georgy Smirnov that appear in this volume have provided the inspiration to try and re-examine the entire spectrum of Estonia's position between East and West, and to point out the main subjects in this new context and the relationship to the new geography of architecture in the Age of Enlightenment and the stylistic changes of the 19th century.

In the broader sense, we are dealing with an invasion and impulses that introduced high-quality international art to the Baltic provinces and provided a 'border country' with a unique position in regard to the adaptation and interpretation of an international art experience that Russia itself has inherited from Rome, Paris, Dresden and Berlin, 
and which paved the way to a cosmopolitan cultural horizon in both the metropolis and the province. Using a methodological approach, the article deals with both the cultural geography and architectural genesis from the Baroque period to the era of Neoclassicism and from the romantic impulses of the 19th century to the variety of different stylistic impulses characteristic of the end of the era.

In the article, five main problems have been investigated. Firstly, the Great Northern War, which resulted in great geopolitical change and impacted both sides. For the imperial power, the 'window to Europe' through the Baltic countries (Estonia and Latvia) helped establish new cultural relations with the West, and for the Baltic countries, it gave an access to the needed resources. However, the question remains, how deeply did the initiatives of the central government affect the spiritual relations that have developed over the centuries, and what was the actual role of the new utopia in a province where the German language and mentality lived on, and where architecture had an important role to play. The article examines several facts about the first large edifices built by Peter the Great and his Italian-born architects Niccolo Michetti and Domenico Trezzini. If the architectural idiom of Michetti clearly demonstrates his Roman background, then Trezzini, based on the energy of the Baroque, introduced Sebastinao Serlio's influence in which simplicity and clarity were key, and which, in the form of Northern Italian Baroque had acquired more of a graphic than volumetric nature. Much has been written about Trezzini's activities related to Peter the Great's summer palace in Katharinenthal on the outskirts of Tallinn. But it may be even more important to consider Trezzini's role as the master architect of the tsar's first town palaces, including his residences in Narva and Tallinn. The second issue examined in the article is that of the Russian Orthodox Church as the generator of a new concept of space and form in the province. There is a definite contradiction between the religious and aesthetic sides of the problem In addition to the political dictates coming from the centre of power, the iconography and style has its own rules, thereby providing a reason for analysing the concrete facts in a wider scale. One example is the building history of the large cupola church in Tartu designed by Johann Wilhelm Krause, the university architect. In addition to the impact of the Russian metropolises, Krause was directly influenced by the German tradition and familiar with its architectural theories and examples (L. Chr. Sturm, Chr. L. Stieglitz etc.). The scope of the architecture and aesthetical thought extends far beyond the specific political relationships.

The third topic, which has often been dealt with in Estonian art history, is the German ethos and the impact of the Russian style on the architecture of the Baltic nobility as it appeared at the very beginning of the 19th century, when the large palaces in Horreda, Raikküla. Aaspere, Riispere etc were built. The column and, in a broader sense, the Vitruvian tradition that appeared both on the portico-facades or indoors as columned halls and cupolas, was the symbol of the age. Despite the close relations between the local aristocracy and the Russian court, there are only a few examples that can be directly connected to the most outstanding architects from St Petersburg, such as Jean Vallin de la Mothe, Georg Freidrich Veldten or Carlo Rossi. Despite the lack of concrete data, it was at the beginning of the 19th century (nearly 100 years after the Great Northern War) that Baltic architecture found its place in the space of Russian classical trends and identity.

Fourthly, there is the matter of the dictates of the metropolis and 'obedience' of the province. At the beginning of the new era, the Baltic culture found itself in quite a peculiar situation. On the one hand, the adoption of the international cultural experience, and on the other, a social order that had outlived its time along with an extensive bureaucracy. Just as it was difficult to replace the German language with Russian, the steps taken by the central government to unify the architectural image of the empire by using standardised facades (tipovye fasady) was viewed with scepticism in the province. In 1814 and 1815, only three houses based on approved models were built in the old Hanseatic town; in 1812, 1816 and 1817 none were built in Reval. Time had to pass before the standardised facades were accepted in the town. And even then, they were viewed as being more bureaucratic than essential in nature by the professional architects. Unlike in Tartu and some other Estonian towns, the mentality of the previous ages lived on in Tallinn, Narva and elsewhere.

Finally, the situation changed at the end of the 19th century when the messianic Orthodox mission of the Russification policy culminated in a massive religious conversion movement in the early 1880s. In Tallinn, the Alexander Nevsky Cathedral was built in the most visible location in the city, where only recently the Estonian 
Knighthood had planned to erect a bronze statue of Martin Luther (upon its completion it was installed in front of the parsonage at Keila). Several hundred Orthodox churches were built all over the country.

\section{CV}

Juhan Maiste is Professor and Head of the Department of Art History at the University of Tartu. PhD at the Moscow Central Institute of Art history (1985), doctoral studies at the university of Helsinki, second Doctoral degree at the Estonian Academy of Arts (1995). The annual Baltic prize for the best scientific research (1997). Fellow and scholarships at the universities of Stockholm, Oxford, British Academy, and ICCROM in Rome. Visiting professor at the universities of Helsinki, Turku, Oulu in Finland, Greifswald, La Sapienza in Rome and others. Doctor Honoris Causa of the Latvian Academy of Sciences. Main fields of study: classical ideal and its reflections in the Renaissance and Neoclassicism in Northern Europe and Baltic countries, manor architecture, the university landscape of the Enlightenment period. He is author of several monographs on philosophy and the poetics of art history, cultural heritage and landscape architecture. The editor-in-chief of the Baltic Journal of Art History. Recent publications include: series of publications on the architectural and cultural history of Tartu University and the architecture of Johann Wilhelm Krause (V volumes, 1999-2016), Eesti kunsti ajalugu = History of Estonian Art, 1770-1830 (ed. by Juhan Maiste, 2016). 